\title{
ARTICLE
}

\section{SPARE THE ROD, SPOIL THE DIRECTOR? REVITALIZING DIRECTORS' FIDUCIARY DUTY THROUGH LEGAL LIABILITY}

\author{
Lisa M. Fairfax*
}

TABLE OF CONTENTS

I. INTRODUCTION

II. SARBANES-OXLEY AND THE FEDERALIZATION OF

DIRECTORS' DUTY OF CARE.

III. SARBANES-OXLEY AND THE DIRECTOR EXONERATION

TREND

A. Sarbanes-Oxley and Director Liability...

B. Comparison with Director Liability Under Corporate

Fiduciary Law

1. Procedural Hurdles and the Demand

Requirement.

2. The Business Judgment Rule ..............................409

3. Exculpatory Statutes, Indemnification, and

Insurance

C. Sarbanes-Oxley and Indirect Implications for

Director Liability.

1. Implications at the State Level

* Associate Professor of Law, University of Maryland School of Law. I would like to thank the faculties at Washington and Lee University School of Law and Wake Forest University School of Law, including Michael Green, Lyman Johnson, Peter Kostant, Blake Morant, and Alan Palmiter, as well as the panelists and participants at the panel on "Recent Reform on the Structure of Corporate Governance" at the Law and Society Association's 2004 Annual Meeting for their insightful comments and suggestions on earlier versions of this draft. Special thanks to Roger A. Fairfax, Jr. for his thoughtful comments on this Article. 
IV. The CONSEquences of SPARING THE RoD ON DIRECTOR BEHAVIOR

A. . . Ashes, Ashes, They All Fall Down: The Failings of Extra-Legal Measures.

B. Reexamining the Utility of Legal Sanctions

1. Legal Sanctions and the Nature of Director Misconduct...

2. Legal Sanctions and Their Deterrent Value

C. Birds of a Feather ... : The Interdependence of

Legal and Extra-Legal Forces.

1. Deterrence and the Laws of Reputation.

2. Deterrence and the Laws of the Market.

D. The Corporate Catch-22 and the Costs of Director

Liability

V. CONCLUSION

\section{INTRODUCTION}

When it comes to corporate directors, it appears that our society has tacitly agreed to spare them any significant legal liability ${ }^{1}$ for failing to perform their duties as board members. Thus, over the last twenty years, there has been a virtual elimination of legal liability - particularly in the form of financial penalties-for directors who breach their fiduciary duty of care. ${ }^{2}$ This is true despite the fact that we entrust directors with the awesome responsibility of monitoring all of America's corporations as well as the officers and agents within those corporations. $^{3}$ More surprisingly, at least from a statutory perspective, ${ }^{4}$ this tacit agreement against legal liability for

1. This Article uses the term "legal liability" or "legal sanctions" to refer to financial liability or incarceration imposed by law on individuals and encompasses both civil and criminal liability. This Article uses the term "director liability" to refer to legal liability imposed on corporate directors.

2. See infra Part III.B (explaining various mechanisms that allow directors to avoid financial liability for breaching their duty of care).

3. See MODEL Bus. CORP. ACT ANN. § 8.01 (2002) ("All corporate powers shall be exercised by or under the authority of, and the business and affairs of the corporation managed by or under the direction of, its board of directors ...."); DEL. CODE ANN. tit. 8, $\S 141$ (a) (2001) (providing that the "business and affairs of every corporation . . . shall be managed by or under the direction of a board of directors").

4. As this Article was going to press, directors at WorldCom agreed to a settlement in which they would personally pay $\$ 18$ million of a $\$ 54$ million settlement with shareholders, while directors at Enron Corp. agreed to personally pay $\$ 13$ million of a 
directors appears to have remained in place even after the wave of corporate governance scandals and reform efforts aimed at preventing their future recurrence. Thus, while the SarbanesOxley Act of 2002 ("Sarbanes-Oxley" or "the Act") imposes increased responsibilities on directors, it fails to impose any direct legal penalties on directors who breach those responsibilities. ${ }^{6}$

Most corporate scholars appear to support the notion that corporate directors should be spared legal liability for their misconduct on corporate boards. ${ }^{7}$ These scholars not only insist that other extra-legal measures sufficiently ensure directors' compliance with their fiduciary duties, but also argue that legal remedies are both costly and ineffective. ${ }^{8}$ Thus, the scholars conclude that legal measures are neither necessary nor appropriate for regulating director behavior. ${ }^{9}$

This Article disagrees with the majority of scholars' conclusion and asserts that legal liability represents an essential mechanism for ensuring directors' fidelity to their fiduciary duties and for questioning reform efforts that do not include such liability. In this regard, Sarbanes-Oxley represents an ideal vehicle for exploring the broader issue of whether a corporate governance system that shields its directors from legal liability can curb directors' irresponsibility and the abuses that result from that irresponsibility.

Part I of this Article examines the provisions of SarbanesOxley that impose specific duties on corporate directors and demonstrates that Sarbanes-Oxley "federalizes" many components of directors' fiduciary duty of care. Part I also pinpoints instances of inappropriate director conduct that suggest a need for such federalization. Part II analyzes SarbanesOxley's impact on corporate director liability by exploring the Act's provisions for director liability and comparing those provisions with both the Act's provisions for officer liability and the state and other federal mechanisms for director liability. Part

$\$ 168$ million settlement with shareholders. See Ben White, Former Directors Agree to Settle Class Actions; Enron, WorldCom Officials to Pay Out of Pocket, WASH. Post, Jan. 8, 2005 , at E01. For a discussion of the possible ramifications of this settlement, see infra Part III.C.

5. Pub. L. No. 107-204, 116 Stat. 745-810 (codified at scattered sections of 11, 15, 18, 28, and 29 U. S. C. (Supp. II 2004)) (2002).

6. See infra Part III.A.

7. See infra Part III.A.

8. See infra Part III.A (emphasizing the impact of capital markets and reputational sanctions on director conduct).

9. See infra Part III.A. 
II also suggests that although Sarbanes-Oxley may have some indirect (and unintentional) impact on directors' exposure to legal liability, this impact may ultimately fail to alter the state law trend of eliminating director liability.

In light of this failure, Part III explores whether legal liability is necessary to ensure directors' adherence to their duty of care. Part III begins with an analysis of arguments rejecting reliance on legal sanctions, including those that stress the positive impact of extra-legal sanctions on director conduct and those that question the ability of legal sanctions to constrain such conduct. Part III asserts that these arguments underestimate the deterrent value of legal penalties and fail to appreciate the degree to which extra-legal measures such as the market or reputational sanctions depend on legal measures for their effectiveness. This assertion is based in part on an assessment of recent empirical evidence affirming the ability of legal sanctions to influence corporate behavior. Part III concludes by addressing those who conclude that legal sanctions are too costly. Although Part III demonstrates that many have overemphasized the costs of legal liability, it nevertheless offers some measures for reducing those costs.

Based on Part III's analysis, this Article concludes that legal sanctions represent a vital aspect of any system seeking to regulate director conduct. Consequently, reforms like SarbanesOxley may be defective because although they require directors to oversee many aspects of a corporation's financial reporting, they make no specific provisions for sanctioning directors' failure to fulfill this function.

\section{SARBANES-OXLEY AND THE FEDERALIZATION OF DiRECTORS' DUTY OF CARE}

State corporate statutes grant a significant amount of power to corporations' boards of directors. ${ }^{10}$ Indeed, these statutes generally require that all corporate power be managed by or under the direction of a board of directors. ${ }^{11}$ In practice, officers and agents-not directors-manage the day-to-day affairs of the

10. See Robert W. Hamilton, Reflections of a Reporter, 63 TEX. L. REV. 1455, 1455 n.4 (1985) (stating that the 1950 Model Business Corporations Act "served as the basis of codification for the corporation statutes of nine states from 1950 through 1959 and eleven additional states from 1960 through 1969" and that "a number of provisions in other state statutes have also been influenced by Model Act provisions").

11. See supra note 3 (noting that by statute all corporate powers are managed by or under the authority of the corporation's board of directors). 
corporation. ${ }^{12}$ However, corporate statutes remind us that any power these officers and agents wield ultimately stems from the power that directors confer upon them. ${ }^{13}$

Statutes do not grant directors this power without some corresponding obligation. Instead, statutes and case law impose upon directors a responsibility to ensure that their corporate power is exercised appropriately. This responsibility takes the form of a fiduciary duty of care to act in the best interests of the corporation. ${ }^{14}$ This duty not only encompasses a director's individual actions, but also encompasses a director's responsibility to oversee the actions of those to whom she delegates power. ${ }^{15}$ Thus, directors have an obligation to monitor corporate actors and remain informed about corporate operations. ${ }^{16}$ Indeed, directors can be held liable for a breach of

12. See Rosenblatt v. Getty Oil Co., 493 A.2d 929, 943 (Del. 1985) ("The realities of modern corporate life are such that directors cannot be expected to manage the day-to-day activities of a company."); see also The Business Roundtable, Principles of Corporate Governance, May 2002, at 2, available at http://www.businessroundtable.org/pdf/704.pdf [hereinafter Business Roundtable] (noting that board members delegate to managers the authority and responsibility for the "everyday affairs of the corporation").

13. This is not to say that statutes do not grant officers authority, but rather that officers' authority often is derivative of directors' authority. See MODEL BUS. CORP. ACT ANN. $\$ 8.41$ (2002) (noting that each officer has the authority set forth in the corporation's bylaws or as prescribed to her by the board).

14. See MODEL Bus. CORP. ACT ANN. § 8.30(a) (2002) ("Each member of the board of directors, when discharging the duties of a director, shall act: (1) in good faith, and (2) in a manner the director reasonably believes to be in the best interests of the corporation."); $\$ 8.31 \mathrm{cmt}$. (noting that the standard of conduct in section 8.30 is frequently referred to as a "director's duty of care"). The duty of care provides the standard of conduct to which directors must comply with respect to all ordinary actions. See $\S 8.30$ (a). Hence, this Article focuses on that duty and the conduct that it encompasses. For transactions involving a conflict of interest, directors have a fiduciary duty of loyalty, which essentially ensures that directors act in good faith when they engage in transactions that might create a conflict of interest. See, e.g., DEL. CODE ANN. tit. 8, § 144 (2001) (providing that conflict of interest transactions be approved by disinterested shareholders or directors or be intrinsically fair to the corporation); Weinberger v. UOP, Inc., 457 A.2d 701, 710 (Del. 1983) ("When directors of a Delaware corporation are on both sides of a transaction, they are required to demonstrate their utmost good faith and the most scrupulous inherent fairness of the bargain."); MODEL BUS. CORP. ACT ANN. § 8.31(a)(2)(iii) (2002) (providing that directors may be subject to liability for actions involving conflicts of interest that are not in the best interests of the corporation).

15. See Graham v. Allis-Chalmers Mfg. Co., 188 A.2d 125, 130 (Del. 1963) (reasoning that the "duties [of directors] are those of control ... [and that the] exercise [of] proper control depends on the circumstances and facts of the particular case"); Briggs v. Spaulding, 141 U.S. 132, 147 (1891) (stating that directors have a duty to "supervise the business with attention ... [and] use proper care in the appointment of agents"); MODEL BUS. CORP. ACT ANN. § 8.31(f) cmt. (2002) (noting that directors have a decisionmaking responsibility and an oversight function).

16. See Model Bus. CoRP. ACT ANN. $§ 8.30$ (2002) (requiring directors to "devot[e] attention to their oversight function"); see also Smith v. Van Gorkom, 488 A.2d 858, 875 (Del. 1985) (stating that directors have a duty to make reasonable inquiry of corporate executives before approving a cash-out merger); Aronson v. Lewis, 473 A.2d 805, 812 (Del. 
their fiduciary duty of care only if they neglect to monitor the corporation's business and affairs properly by failing to make appropriate inquiries into corporate matters or by failing to devote sufficient attention to those matters. ${ }^{17}$ Case law emphasizes that directors' fiduciary duty specifically includes a responsibility to keep abreast of the corporation's financial affairs. ${ }^{18}$ Ultimately, directors' fiduciary duty of care to remain informed and ask probing questions of managers is designed to protect against abuse of power by directors as well as by the officers and agents who serve at the directors' pleasure. ${ }^{19}$

Investigative reports indicate that directors at Enron Corp. ("Enron") ${ }^{20}$ and at other corporations embroiled in financial accounting scandals ${ }^{21}$ failed to fulfill their fiduciary duties. The reports not only reveal defects in directors' individual behaviors, but more importantly reveal their failure to monitor adequately and remain sufficiently informed about the behavior of others upon whom they bestowed power. ${ }^{22}$ Congressional testimony has

1984) (mandating that "directors have a duty to inform themselves, prior to making a business decision, of all material information reasonably available to them"); Francis v. United Jersey Bank, 432 A.2d 814, 822 (N.J. 1981) ("Directors are under a continuing obligation to keep informed about the activities of the corporation.").

17. See MOdEL Bus. CORP. ACT ANN. § 8.31(a)(2)(iv) (2002).

18. See, e.g., Francis, 432 A.2d at 822 (noting the directors have a responsibility to maintain familiarity with the company's financial affairs); Henshaw v. Am. Cement Corp., 252 A.2d 125, 128 (Del. Ch. 1969) (finding that the director has a right and "often has a duty" to inspect the corporation's books).

19. See Troy A. Paredes, Enron: The Board, Corporate Governance, and Some Thoughts on the Role of Congress, in ENRON: CORPORATE FIASCOS AND THEIR IMPLICATIONS 495, 498-99 (Nancy B. Rapoport \& Bala G. Dharan eds., 2004) (asserting that directors need to monitor their officers because some officers may be "inclined to shirk or otherwise act in their own self-interest").

20. For a discussion of Enron Corp., see generally ENRON: CORPORATE FIASCOS AND Their ImPliCATiOns (Nancy B. Rapoport \& Bala G. Dharan eds., 2004). See also John C. Coffee, Jr., Understanding Enron: "It's About the Gatekeepers, Stupid", 57 Bus. Law. 1403, 1403-04, 1412, 1419 (2002) (concluding that the Enron collapse was more about "gatekeeper" failure than Board failure); Jeffrey N. Gordon, Governance Failures of the Enron Board and the New Information Order of Sarbanes-Oxley, 35 ConN. L. REV. 1125, 1127 (2003) (critiquing the performance of the Enron Board); Joan MacLeod Heminway, Enron's Tangled Web: Complex Relationships; Unanswered Questions, 71 U. CIN. L. REV. 1167, 1177-81 (2003) (exploring agency relationships in publicly-held corporations as they related to the Enron collapse); Marleen A. O'Connor, The Enron Board: The Perils of Groupthink, 71 U. CIN. L. REV. 1233, 1237 (2003) (using the "groupthink" theory to analyze the Enron Board's failure to monitor related-party transactions).

21. For a discussion of other corporate governance scandals, see generally Lisa M. Fairfax, Form Over Substance?: Officer Certification and the Promise of Enhanced Personal Accountability Under the Sarbanes-Oxley Act, 55 RUTGERS L. REV. 1, 6-8 (2002).

22. The chairman of the U.S. Senate Permanent Subcommittee on Investigations concluded that the Enron Board "knew about numerous questionable practices by Enron management over several years, but it chose to ignore these red flags." 148 CONG. REC. S6561-64 (daily ed. July 10, 2002) (statement of Sen. Levin, chairman of Permanent Subcommittee on Investigations) [hereinafter Subcommittee on Investigations Report]. 
confirmed that these directors understood their obligation to monitor the corporation and its financial affairs. ${ }^{23}$ Despite this understanding, some directors have admitted to signing off on company reports with limited or no knowledge of their contents, while others have admitted to approving transactions even when they did not fully understand them. ${ }^{24}$ Still other directors made decisions regarding highly complex transactions after only brief consideration of the issues critical to those transactions. ${ }^{25}$ These actions appear contrary to the directors' duty to remain informed and suggest that instead of providing a vigorous check on managerial conduct, the directors merely rubber-stamped management's decisions. ${ }^{26}$ Then too, despite their awareness of potential risk, ${ }^{27}$ directors only made cursory inquiries into transactions involving conflicts of interest or high-risk hedge activity. $^{28}$ Again, such conduct seems inconsistent with the directors' fiduciary obligation to ask probing questions before approving company transactions.

Although there were many reasons for the corporate governance failures exhibited by Enron and other entities, ${ }^{29}$ the reports note that the fact that directors did not diligently perform

Similarly, the special investigative committee of Enron's board, appointed by Congress and chaired by William C. Powers, concluded that the board failed to live up to its oversight responsibilities with respect to various related party transactions. See Report of Investigation by the Special Investigation Committee of the Board of Directors of Enron Corp., Feb. 1, 2002, 149 [hereinafter Powers Report] (noting the Enron board members' failure to make the inquiries necessary under the Enron Code of Conduct to permit approval of conflict of interest transactions between Enron and its CFO); id. at 157 (citing lack of detailed questions related to certain business transactions); id. at 162-64 (noting the limited board review of major transactions).

23. See S. Rep. No. 107-70, at 14-15, 24-37 (2002) (citing statements of various Enron board members detailing the responsibilities of board and committee members and criticizing the general lack of oversight).

24. See Jackie Spinner \& David S. Hilzenrath, Enron CEO Felt "Betrayed," Panel Told: Head of Internal Probe Testifies on the Hill, WASH. Post, Feb. 6, 2002, at A1 (reporting that former Enron chairman Kenneth Lay claimed that he did not pay enough attention or fully appreciate financial information within company documents); see also Subcommittee on Investigations Report, supra note 22, at S6564 (noting that Enron board members who signed company financial statements "claimed they didn't know what was going on in the company"); Powers Report, supra note 22, at 162-64 (finding that the Enron Board made decisions about various transactions without considering critical issues and information relevant to those transactions).

25. See Powers Report, supra note 22, at 162-64 (pointing out the Enron Board's limited scrutiny of various conflict of interest transactions).

26. See Paredes, supra note 19, at 504, 535.

27. See Powers Report, supra note 22, at 154-56 (noting the Enron directors' awareness of the risky nature of the transactions they approved).

28. See id. at 149, 157 (pinpointing limited inquiries concerning specific conflict of interest transactions and hedging activity).

29. See generally Fairfax, supra note 21 (discussing some of the other corporate scandals of recent years). 
their oversight functions significantly contributed to these failures. ${ }^{30}$ As the primary monitors of the corporate enterprise, directors serve as one of the primary, and possibly final, checks on misbehavior within that enterprise. ${ }^{31}$ As a consequence, "to the extent that other corporate governance devices fail, the board of directors becomes all the more important." ${ }^{32}$ In other words, given their role within the corporate structure, directors' failure to fulfill their fiduciary duty of diligently seeking to curb abuses of power is particularly problematic. From this perspective, by failing to perform their monitoring duties with sufficient rigor, Enron directors acquiesced in, and thus contributed to, corporate misconduct. ${ }^{33}$

In an apparent effort to restore directors' adherence to their fiduciary duty, Sarbanes-Oxley imposes responsibilities on directors similar to the responsibilities required under state corporate fiduciary law, appearing to "federalize" that law. ${ }^{34}$ Most notably, Sarbanes-Oxley enhances the monitoring role of directors by making directors who serve on the audit committee of a corporation responsible for closely overseeing auditors' work as well as any disagreements related to that work. ${ }^{35}$ Indeed, the provision of Sarbanes-Oxley that most comprehensively impacts

30. See Subcommittee on Investigations Report, supra note 22, at S6564 (noting that Enron board members' failure to curb high risk accounting practices and various conflicts of interest contributed to the collapse of Enron). After his investigation of Enron, William Powers concluded that the company's fraudulent transactions "could and should have been avoided" if executives and board members had taken their fiduciary obligations more seriously. The Financial Collapse of Enron-Part 1: Hearing Before the Subcomm. on Oversight and Investigations of the House Comm. on Energy and Commerce, 107th Cong. 18-19 (2002) (statement of William C. Powers, Jr., Chairman of the Special Investigative Committee of the Board of Directors of Enron Corporation); see also Carrie Johnson, Enron Board Aided Collapse, Senate Panel Says: Report Finds Directors Approved Conflicts of Interest, Large Cash Bonuses, WASH. Post, July 7, 2002, at A10 (citing Senate reports of Enron directors ignoring questionable practices and permitting questionable high-risk practices).

31. See Marin Lipton, Some Thoughts for Boards of Directors, 1467 PraCtising L. Inst., CORP. L. \& PRAC. HANDBOOK SERIES 131, 138 (2005) (describing directors as "monitors" and "gatekeepers").

32. Paredes, supra note 19, at 504.

33. Subcommittee on Investigations Report, supra note 22, at S6564 (noting that the directors failed to protect Enron shareholders and that such failure contributed to Enron's collapse); see also Johnson, supra note 30 (reporting the Senate report's conclusion that Enron directors' failure to sufficiently probe conflict of interest transactions contributed to the firm's collapse).

34. For a discussion of the federalization of corporate law, see generally Stephen M. Bainbridge, A Critique of the NYSE's Director Independence Listing Standards, 30 SEC. REG. L.J. 370, 396-99 (2002); Larry E. Ribstein, Market vs. Regulatory Responses to Corporate Fraud: A Critique of the Sarbanes-Oxley Act of 2002, 28 J. CoRP. L. 1, 57-61 (2002).

35. See Sarbanes-Oxley Act § 301, 15 U.S.C. $§ 78 j-1(m)$ (Supp. II 2002). 
corporate directors' conduct relates to the audit committee of a corporation's board of directors. ${ }^{36}$ Section 301 requires companies to have an audit committee comprised solely of independent directors $^{37}$ and makes the audit committee responsible not only for appointing and compensating the company's auditors, but also for overseeing the work of the auditors. ${ }^{38}$ Sarbanes-Oxley further requires the audit committee to oversee any financial reporting disagreements between the corporation's management and its auditors. ${ }^{39}$ Additionally, audit committees must establish procedures for receiving and treating complaints relating to accounting or auditing matters, including procedures for anonymous submission by employees who have concerns regarding questionable accounting or auditing practices. ${ }^{40}$

Through these provisions, Sarbanes-Oxley imposes an oversight function on audit committee members similar to directors' more general monitoring duty under state fiduciary law. And like state law, this oversight function apparently includes a responsibility to remain informed and make queries about the financial work of auditors. ${ }^{41}$ Specifically, by making audit committee members responsible for management disagreements as well as employee complaints about financial matters, Sarbanes-Oxley requires audit committee members to remain informed about accounting and financial processes and to

36. Indeed, one of the Act's key provisions is the creation of a Public Accounting Oversight Board, whose members are appointed by the SEC and whose function is to oversee the audit of public companies and ensure the independence of audit reports. See Sarbanes-Oxley Act $\S 101,15$ U.S.C. $§ 7211$. Other provisions that relate to directors include Section 305 of Sarbanes-Oxley, which expands the ability of the Securities and Exchange Commission (the "SEC") to bar and penalize directors, Sarbanes-Oxley Act $\S 305$ (amending 15 U.S.C. $\$ \S 77 \mathrm{t}(\mathrm{e}), 78 \mathrm{u}(\mathrm{d})$ ); Section 306, which prohibits directors from trading in company securities during pension fund "blackout" periods, Sarbanes-Oxley Act $\S 306$, 15 U.S.C. $\S 7244$; and Section 402 , which prohibits personal loans to directors, Sarbanes-Oxley Act $\S 402$, 15 U.S.C. $\$ 78 \mathrm{~m}$.

37. Sarbanes-Oxley Act $\S 301,15$ U.S.C. $\S 78 \mathrm{j}-1(\mathrm{~m})(3)$. In order to be considered independent, an audit committee member may not accept any compensation from the issuer other than in her capacity as a board committee member and may not be affiliated with the company or its subsidiaries. Id. Audit committees must also "disclose whether or not ... at least one member is a 'financial expert." Sarbanes-Oxley Act $\S$ 407, 15 U.S.C. $\S 7265$.

38. Sarbanes-Oxley Act $\S 301(\mathrm{~m})(2), 15$ U.S.C. $\S 78 \mathrm{j}-1(\mathrm{~m})(2)$

39. Id.

40. See id. § 301(m)(4)(A)-(B), 15 U.S.C. $\S 78 \mathrm{j}-1(\mathrm{~m})(4)$.

41. Compare Sarbanes-Oxley Act $\S 301(\mathrm{~m})(2), 15$ U.S.C. $\S 78 \mathrm{j}-1(\mathrm{~m})(2)$ (requiring that the audit committee of the board of directors oversee financial auditor's work) with Francis v. United Jersey Bank, 432 A.2d 814, 821-22 (N.J. 1981) (discussing a director's duty to remain informed about their corporation's financial status through the periodic review of financial statements, the frequency of which depends on the size of the corporation). 
ask probing questions about these processes. ${ }^{42}$ This responsibility also ensures that directors are aware of possible financial problems. Like state fiduciary law, these provisions of SarbanesOxley particularly focus directors' attention on the financial affairs of the corporation, making audit committee directors ultimately responsible for monitoring the flow of financial information within the corporation.

While Sarbanes-Oxley imposes primary responsibility for internal control procedures on management, these requirements also impact the board of directors. Section 302 of Sarbanes-Oxley requires a company's CEO and CFO to certify in each annual or quarterly report both that they are responsible for establishing and maintaining internal controls designed to ensure that material information is made known to them and that they have evaluated the effectiveness of those controls. ${ }^{43}$ Section 302 also requires these officers to disclose to the board's audit committee any significant deficiencies in the design or operation of the internal controls that could adversely affect the company's ability to record and report financial data. ${ }^{44}$ These disclosure obligations implicate the directors' duty to keep abreast of corporate financial affairs and the transactions underlying those affairs. Then too, because audit committee directors must receive reports about deficiencies in the internal control process, they may have an obligation to respond to those reports. This obligation suggests that directors must remain knowledgeable about corporate internal controls and ask questions about those controls and their defects. In this respect, section 302 implicates directors' monitoring responsibilities embedded in the duty of care.

A similar implication arises from another Sarbanes-Oxley's provision involving internal control procedures. Section 404 requires that each annual report "state the responsibility of management for establishing.... adequate internal control structure[s] and procedures" and include "an assessment... of the effectiveness of [those controls] and procedures." information implicates the board because at least a majority of board members must sign the annual report. ${ }^{46}$ The SEC

\footnotetext{
42. Sarbanes-Oxley Act § 301, 15 U.S.C. § 78j-1(m)(2), (m)(4).

43. Sarbanes-Oxley Act $\S 302(\mathrm{a}), 15$ U.S.C. $\$ 7241(\mathrm{a})(4)$.

44. Id., 15 U.S.C. $§ 7241(\mathrm{a})(5)$.

45. Sarbanes-Oxley Act $\S 404(a), 15$ U.S.C. $§ 7262(a)$.

46. Congress amended the signature requirements for annual reports in 1980 to require that the $\mathrm{CEO}$, the $\mathrm{CFO}$, and a majority of the board sign such reports. See Accounting Releases, Amendments to Annual Report Form, Securities Act Release No. 6231, Exchange Act Release No. 17,114, [1937-1982 Transfer Binder] Fed. Sec. L. Rep.
} 
maintains that directors who sign the annual report implicitly assert their belief in the accuracy of the report. ${ }^{47}$ In order to support this belief, directors who sign annual reports should familiarize themselves with the information contained within. Thus, while board members do not have a direct obligation with respect to internal control procedures, their signing responsibilities require them to monitor and remain informed about those procedures.

The Act's rules regarding attorneys also impose fiduciarylike obligations on directors, making them directly or indirectly responsible for receiving and responding to complaints about securities fraud or fiduciary duty violations. ${ }^{48}$ Section 307 of Sarbanes-Oxley directs the SEC to establish a rule requiring attorneys who appear or practice before the SEC "to report evidence of a material violation of securities law or breach of fiduciary duty ... by the company" or its agent to the chief legal counsel or CEO of the company. ${ }^{49}$ Section 307 further provides that if either counsel or the CEO does not appropriately respond to this evidence, the attorney must report the evidence to the audit committee, another committee of independent directors, or the entire board of directors. ${ }^{50}$ The SEC codified this provision in Rule 205 of the Securities Exchange Act of 1934, as amended (the "Exchange Act"). ${ }^{51}$ Additionally, the SEC provided for an alternative procedure. $^{52}$ To this end, Rule 205 also allows corporations to establish a qualified legal compliance committee

(CCH) II 72,301, at 62,812-13 (Sept. 2, 1980) (amending signature requirement for annual report).

47. Audit Committee Disclosure, Exchange Act Release No. 41,987, [1999-2000 Transfer Binder] Fed. Sec. L. Rep. (CCH) II 86,209, at 82,414 (Oct. 7, 1999).

48. For an in-depth analysis of Section 307, see Roger C. Cramton et al., Legal and Ethical Duties of Lawyers After Sarbanes-Oxley, 49 VILL. L. REV. 725, 740-71 (2004); Susan J. Stabile, Sarbanes-Oxley's Rules of Professional Responsibility Viewed Through a Sextonian Lens, 60 N.Y.U. ANN. SuRV. AM. L. 31, 37-42 (2004).

49. Sarbanes-Oxley Act $\S 307(1), 15$ U.S.C. $§ 7245(1)$ (Supp. II 2004). Although Congress intended this rule to apply to all lawyers practicing before the SEC, the SEC narrowed the application and therefore excluded certain categories of lawyers, including some foreign lawyers and those who appear before the SEC outside of the attorney-client relationship. See 17 C.F.R. $\$ 205.2(a)(1)$, (2) (2004); see also Cramton et al., supra note 48, at 740-51 (discussing the kinds of lawyers who fall within the SEC's definition).

50. Sarbanes-Oxley Act $\S 307(2), 15$ U.S.C. $§ 7245(2)$; see also Cramton et al., supra note 48, at 751-79 (discussing conduct that triggers attorneys' reporting duties); Stabile, supra note 48 , at $41-42$ (analyzing reporting requirements).

51. See 17 C.F.R $\S 205.3(b)$ (stating that if an attorney becomes aware of a violation, "the attorney shall report such evidence to the issuer's chief legal officer . . . or to both the issuer's chief legal officer and its chief executive officer").

52. See 17 C.F.R. $§ 205.3(\mathrm{c})$. 
(QLCC), ${ }^{53}$ which must (1) be composed of independent directors and (2) have "procedures for the confidential receipt, retention, and consideration... of evidence" involving securities fraud or fiduciary duty breaches. ${ }^{54}$ If a QLCC exists, an attorney may report to the QLCC instead of reporting to counsel or the CEO. ${ }^{55}$ The QLCC then has the responsibility of determining if an investigation is warranted and if so, the QLCC must initiate one. ${ }^{56}$ Following an investigation, the QLCC must recommend an appropriate response and inform the audit committee or the entire board of that response. ${ }^{57}$

These provisions require directors to remain informed and to monitor not only attorneys, but also other agents in the corporation who may be engaged in fraudulent activities. ${ }^{58}$ Indeed, whether a corporation has a QLCC or not, SarbanesOxley requires board members to conduct some form of investigation into and make appropriate inquiries about violations of relevant laws. ${ }^{59}$ This requirement should ensure that directors will be heavily involved with internal investigations of their corporation and it does augment directors' duty of care in this area. ${ }^{60}$

Taken together, these provisions of Sarbanes-Oxley impose fiduciary-like duties on directors. While several cases suggest that directors generally already have a duty to oversee the financial affairs of their corporation, including its internal control procedures, ${ }^{61}$ Sarbanes-Oxley adds teeth to the directors'

53. See 17 C.F.R. $\S 205.2(\mathrm{k})$ (setting forth the requirements for establishing a QLCC).

54. Id. At least one member of the committee must be a member of the board's audit committee. $I d$.

55. Id. $\S 205.3(\mathrm{c})(1)$.

56. Id. § 205.3(c)(2).

57. $\quad I d . \S 205.2(\mathrm{k})$.

58. See id. § 205.3(c)(1) (allowing attorneys to report violations "by the issuer or by any officer, director, employee, or agent of the issuer").

59. See supra notes 30-35 and accompanying text.

60. Cramton notes that the obligations imposed upon securities lawyers by Sarbanes-Oxley are not new, but instead "reflect the duties of lawyers under the ethics rules of the vast majority of American jurisdictions." Cramton et al., supra note 48, at 830. However, even if reporting obligations are not new, their "federalization" may encourage attorney adherence to these rules in a manner similar to the goal of directors' obligations. See id.

The characterization of these rules as novel requirements that would result in a fundamental change in the relationship of a lawyer to a corporate client is hot air: a hullabaloo stirred up primarily to defeat or limit a new vehicle of regulation that might, unlike the disciplinary process of the states, provide a Id. substantial deterrent to lawyer assistance of corporate fraud and criminality.

61. For a discussion of these duties, see In re Caremark Int'l Inc. Derivative Litig., 
obligation by creating some greater specificity regarding this duty. Moreover, these requirements regulate the internal operations of corporate boards in a manner traditionally reserved to the states. ${ }^{62}$ In this way, Sarbanes-Oxley not only federalizes corporate fiduciary duties, but also adds substance to them. This federalization represents an attempt to restore directors' fidelity to their fiduciary duties. The critical question, however, is whether that attempt will prove successful.

\section{SARBANES-OXLEY AND THE DIRECTOR EXONERATION TREND}

Seeking to answer the above question, this Part explores the impact of Sarbanes-Oxley on director liability. This exploration reveals that although Sarbanes-Oxley increases the duties of directors, the Act fails to provide significant direct provisions for ensuring that directors comply with those increased new duties. This failure appears intentional given the stark contrast between the Act's treatment of directors and that of officers, who face personal liability for noncompliance with the Act. Moreover, it appears consistent with the state law trend toward virtual elimination of director liability. ${ }^{63}$ Although this Part reveals that Sarbanes-Oxley indirectly may serve to undercut this trend, it questions whether indirect measures will be sufficient to ensure

698 A.2d 959, 970 (Del. Ch. 1996).

[C]orporate boards [could not] satisfy their obligation to be reasonably informed concerning the corporation, without assuring themselves that information and reporting systems exist in the organization that are reasonably designed to provide to senior management and to the board itself timely, accurate information sufficient to allow management and the board, each within its scope, to reach informed judgments concerning both the corporation's compliance with law and its business performance. Id.

62. Listing requirements, such as those promulgated by the New York Stock Exchange, also serve to impose requirements on the internal operations of corporations in a manner traditionally reserved to state law. See Bainbridge, supra note 34, at 396-97; see also Lyman P. Q. Johnson \& Mark A. Sides, The Sarbanes-Oxley Act and Fiduciary Duties, 30 WM. Mitchell L. Rev. 1149, 1216-17 (2004) (noting that Sarbanes-Oxley creates a new federal presence and that it may impact the analysis of directors' fiduciary duties).

63. This examination of state law focuses on Delaware because it stands as the state with the largest number of public corporations and hence the most influential corporate law regime. See, e.g., S. Samuel Arsht, A History of Delaware Corporation Law, 1 DEL. J. CORP. L. 1, 1 (1976) (stating that Delaware corporate law is "the most popular of such laws in the United States"); Marc Gunther, Ovitz v. Eisner: Boards Beware!, FORTUNE, Nov. 10, 2003, at 171, 172 (reporting that "more than half of the Fortune 500" are incorporated in Delaware); R. Cammon Turner, Shareholders vs. The World; Revlon Duties' and State Constituency Statutes, Bus. L. TODAY, Jan.-Feb. 1999, at 34 (stating that Delaware is the "state of incorporation of more than 40 percent of the companies listed on the New York Stock Exchange" and that "[m]ost states . . look to Delaware law when interpreting local corporate law"). 
that directors face legal liability for breaches of their fiduciary obligations.

\section{A. Sarbanes-Oxley and Director Liability}

Sarbanes-Oxley only includes two provisions that specifically impose legal liability on directors for their service. First, the Act expands the SEC's ability to remove directors and to bar them from serving on the boards of public companies. Section 305 provides that the SEC can effect such removals and bars by showing a director's "unfitness," as opposed to "substantial unfitness," for the position. ${ }^{64}$ This lowered standard represents an increase in the SEC's ability to remove or bar directors. ${ }^{65}$ Second, section 306 of Sarbanes-Oxley requires directors to disgorge profits realized from trades made during periods when pension rules prevent their company's shareholders from doing the same, defined as pension fund "black-out periods"; 66 it also prohibits directors and officers from trading in their company's stock during such periods ${ }^{67}$ and allows the company or its shareholders to recover any profit realized from trades made during that time. ${ }^{68}$ Such profits are recoverable regardless of a director's intent. ${ }^{69}$ At least in this limited way, Sarbanes-Oxley imposes personal liability on directors. ${ }^{70}$ However, Sarbanes-Oxley fails to impose any legal sanctions on directors who do not comply with their responsibilities under the Act. $^{71}$

64. See Sarbanes-Oxley Act $\S 305$ (striking the term "substantial unfitness" from 15 U.S.C $\S 78 \mathrm{u}(\mathrm{d})(2)$ and 15 U.S.C. $§ 77 \mathrm{t}(\mathrm{e})(2000$ \& Supp. II 2002) and inserting the term "unfitness").

65. See Phillip F.S. Berg, Note, Unfit to Serve: Permanently Barring People from Serving as Officers and Directors of Publicly Traded Companies After the Sarbanes-Oxley Act, 56 VAND. L. REV. 1871, 1888-89 (2003) (explaining that new SEC provisions lower the requisite standard and allow the SEC to suspend directors and officers directly).

66. Sarbanes-Oxley Act $\S 306$ (a), 15 U.S.C. $§ ~ 7244$ (a) (Supp. II 2002). A black-out period is a period of more than three consecutive business days during which at least fifty percent of the beneficiaries or participants in a pension plan do not have the ability to trade company securities. Id. § 306(a)(4), § 7244(a)(4).

67. Id. § 306(a)(1), § 7244(a)(1).

68. Id. $\S 306(\mathrm{a})(2), \S 7244(\mathrm{a})(2)$. Sarbanes-Oxley allows any shareholder to bring an action to recover these profits on behalf of the company if the company refuses to bring such an action within sixty days after the request, or if the company fails to diligently prosecute the action. Id.

69. See id. (requiring that any profit realized by a director during a blackout period "shall inure to and be recoverable by the issuer, irrespective of any intention on the part of such director or executive officer in entering into the transaction").

70. See id. (placing liability on the director for any profit realized during the blackout period).

71. See Jill E. Fisch \& Caroline M. Gentile, The Qualified Legal Compliance Committee: Using the Attorney Conduct Rules to Restructure the Board of Directors, 53 
This failure stands in stark contrast with the Act's liability provision for CEOs and CFOs. Like it does for directors, Sarbanes-Oxley creates new responsibilities for CEOs and CFOs; those responsibilities include requiring such officers to certify the accuracy of financial information within reports their companies file with the SEC. ${ }^{72}$ However, unlike it does for directors, Sarbanes-Oxley specifically ties violations of officer certification responsibilities to legal sanctions. ${ }^{73}$ Thus, section 906 provides that officers who knowingly violate the certification provision face a maximum penalty of one million dollars, a maximum prison term of ten years, or both. ${ }^{74}$ Willful violators face a maximum fine of five million dollars, a maximum of twenty years in prison, or both. ${ }^{75}$ In contrast, Sarbanes-Oxley contains no such liability provisions for directors who violate their obligations relating to the audit committee or to other matters. ${ }^{76}$

In light of the liability imposed upon officers, the lack of liability for directors appears purposeful. Indeed, the existence of section 906 suggests that Congress could have included a parallel section on director liability if it had so desired. The absence of such a section suggests a lack of desire to hold directors legally liable for failing to fulfill their Sarbanes-Oxley responsibilities.

\section{B. Comparison with Director Liability Under Corporate Fiduciary Law}

Because Sarbanes-Oxley imposes duties that are fiduciary in nature, it is possible that Congress believed it could rely on existing corporate governance measures to hold directors liable for breaches of those duties. However, to anyone paying attention to corporate fiduciary law and the sanctions related thereto, this reliance appears misplaced. Over the last twenty years, a variety of mechanisms have contributed to a virtual elimination of legal

DUKE L.J. 517, 519-20 (2003) (noting that "Sarbanes-Oxley did not impose federal standards for director liability").

72. See Sarbanes-Oxley Act $\$ \S 302,906,18$ U.S.C. $\S 1350$ (Supp. II 2002). For a general discussion of the impact of this certification requirement on officers' liability, see Fairfax, supra note 21, at 20-46.

73. See Sarbanes-Oxley Act $§ 906,18$ U.S.C. $\$ 1350$.

74. See id. $\$ 906(c)(1), 18$ U.S.C. $\S 1350(c)(1)$. Previous versions of the Act only authorized a $\$ 500,000$ maximum fine and a five-year prison term, reserving the more significant penalties for willful violations. See, e.g., H.R. 3763, 107th Cong. (2002).

75. Sarbanes-Oxley Act $\S 906(c)(2), 18$ U.S.C. $\S 1350(c)(2)$. These sanctions represent an increase from previous versions of the Act which only subjected officers to a one-million-dollar maximum fine and a ten-year prison term for willful violations. See, e.g., H.R. 3763.

76. See Fisch \& Gentile, supra note 71, at 519-20. 
liability for directors who breach their duty of care under state law. ${ }^{77}$

1. Procedural Hurdles and the Demand Requirement. As an initial matter, the procedural rules related to shareholder suits for fiduciary duty breaches make it difficult for shareholders to even bring an action challenging director conduct in this area. ${ }^{78}$ Before a shareholder can bring a derivative suit alleging a director's violation of her fiduciary duty, most jurisdictions require that a shareholder make a demand on the corporation's board of directors, unless demand is excused, requesting that the board take suitable action against the specified director. ${ }^{79}$ The shareholder's demand allows the board to assess the allegations and determine whether or not a lawsuit is appropriate. ${ }^{80}$ After such an assessment, the board can decide not to bring any action against the director. ${ }^{81}$ This is the decision that most boards reach, ${ }^{82}$ and although shareholders can challenge it, most courts defer to boards on this matter. ${ }^{83}$ Consequently, although the demand requirement was designed to prevent director liability for meritless claims, it also undermines shareholders' ability to hold directors accountable for meritorious claims. ${ }^{84}$ If demand is

77. This elimination appears consistent with other countries. Indeed, a recent study by Professors Bernard Black, Brian Cheffins, and Michael Klausner of six countries, including Australia, Canada, Britain, France, Germany, and Japan, found that directors of public companies in those countries rarely face financial liability in connection with the malperformance of their responsibilities as directors. See generally BERNARD BLACK ET

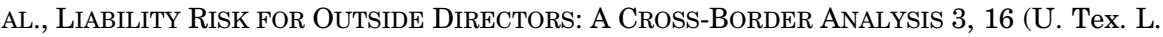
\& Econ. Working Paper No. 27, 2004; Stan. L. \& Econ. Olin Working Paper No. 285, 2004), at http://ssrn.com/abstract=557070; BERNARD BLACK \& BRIAN CHEFFINS, OUTSIDE DiRECTOR LiABILITY ACROSS Countries 92-97 (U. Tex. L. \& Econ. Working Paper No. 31, 2004; Stan. L. \& Econ. Olin Working Paper No. 266, 2004), at http://ssrn.com/abstract= 438321.

78. For other procedural rules that undermine the ability of shareholders to bring derivative actions, see John C. Coffee, Jr. \& Donald E. Schwartz, The Survival of the Derivative Suit: An Evaluation and a Proposal for Legislative Reform, 81 CoLUM. L. REv. 261, 312-14 (1981).

79. See Carol B. Swanson, Juggling Shareholder Rights and Strike Suits in Derivative Litigation: The ALI Drops the Ball, 77 MINN. L. REV. 1339, 1349 \& n.55 (1993).

80. See id. at 1349-50 (noting that the demand process enables board members to analyze derivative actions).

81. Id. at 1350 .

82. Id. at 1350 n. 60 .

83. See id. at 1350 ("[B] usiness executives-not judges-are trained to make this significant business judgment.”).

84. See Coffee \& Schwartz, supra note 78, at 326 ("[T]he ability of even a truly independent board to terminate an action plainly means that meritorious cases will sometimes be aborted.”); Daniel R. Fischel \& Michael Bradley, The Role of Liability Rules and the Derivative Suit in Corporate Law: A Theoretical and Empirical Analysis, 71 CORNELL L. REV. 261, 286 (1986) (noting that liability rules have lost their effectiveness because of procedural hurdles); Harry G. Hutchinson, Presumptive Business Judgment, 
excused because the director is interested in the underlying transaction, shareholders can bring a suit against that director without first making a demand on the board. ${ }^{85}$ However, boards can appoint a special litigation committee of disinterested directors to assess the shareholder's suit, and the board can make a motion to dismiss the suit upon the committee's recommendation. ${ }^{86}$ Not only do most boards make such motions, but in the vast majority of cases courts grant the motion based on the special litigation committee's recommendation. ${ }^{87}$ Thus, whether demand is made or excused, the board of directors, as an entire body or through a committee, generally determines that suits against directors should not proceed. For this reason, scholars agree that the procedural rules related to derivative suits severely limit the ability of shareholders to bring legal actions to impose liability on directors for violating their fiduciary duty.

2. The Business Judgment Rule. Even if shareholders overcome this procedural hurdle, the tremendous deference courts grant to board decisions means that courts hold directors liable for only the most egregious examples of director misconduct. ${ }^{89}$ Courts analyze actions involving breach of a

Substantive Good Faith, Litigation Control: Vindicating the Socioeconomic Meaning of Harhen v. Brown, 26 J. CORP. L. 285, 292 (2001) (outlining procedural requirements that prevent the filing of even meritorious claims); Donald E. Schwartz, In Praise of Derivative Suits: A Commentary on the Paper of Professors Fischel and Bradley, 71 CoRNELL L. REV. 322, 339-40 (1986) (noting that derivative suits are endangered by the Delaware courts' reluctance to excuse demand and imposition of the business judgment rule on those cases in which demand is required); Carol B. Swanson, Corporate Governance: Sliding Seamlessly into the Twenty-First Century, 21 J. CoRP. L. 417, 437 (1996) (explaining that procedural hurdles make it difficult for shareholders to get the merits of their claims before the courts).

85. In some jurisdictions, shareholders do not have to make a demand if their complaint creates a reasonable doubt that "(1) the directors are disinterested and independent and (2) the challenged transaction [is] otherwise the product of a valid exercise of business judgment." Aronson v. Lewis, 473 A.2d 805, 814 (Del. 1984). In such a situation, demand is considered "excused." $I d$. at 815 .

86. Swanson, supra note 79 , at $1356-57$.

87. See id. at 1357-58 ("Management's use of this device has motivated courts to ... defer to the committee's determination more often."); see also Zapata Corp. v. Maldonado, 430 A.2d 779, 784 (Del. 1980) (“[A] board decision ... will be respected unless it was wrongful."); Swanson, supra note 84, at 437 (explaining that "shareholders have tremendous difficulty in getting the merits of the[ir] claim before the court" because of the demand rule).

88. See Swanson, supra note 79, at 1358-59 n.118 (explaining that litigation committees routinely dismiss plaintiffs' actions).

89. In re RJR Nabisco, Inc. S'holders Litig., CIV. A. No. 10389, 1989 WL 7036, at *14 n.13 (Del. Ch. Jan. 31, 1989) (noting that the business judgment rule contemplates limited substantive review for judgments that are "egregious," "irrational," or "so beyond reason"). 
director's fiduciary duty of care under the business judgment rule. $^{90}$ The reliance of courts on this rule reflects an extreme reluctance to interfere with or second guess business decisions of boards. $^{91}$ The justification for this rule is that board members, because of their business background and experience, are bettersuited than courts to make business decisions. ${ }^{92}$ Hence, the business judgment rule protects directors from liability by sanctioning all decisions made in good faith, even if courts disagree with those decisions. ${ }^{93}$ Indicative of this protection, shareholders rarely succeed when they bring actions based on a violation of the directors' fiduciary duty of care. ${ }^{94}$ Smith $v$. Van Gorkom stands out as an important exception because the court in that case found the directors personally liable for breaching their duty of care..$^{95}$ In Van Gorkom, the Delaware Supreme Court held an entire board, consisting of ten directors, liable for

90. See Aronson, 473 A.2d at 811-12 (explaining that the business judgment rule forces the plaintiff to rebut the presumption of good business practices on the part of directors); Charles Hansen, The ALI Corporate Governance Project: Of the Duty of Due Care and the Business Judgment Rule, a Commentary, 41 Bus. LAW. 1237, 1240 (1986) (noting that the "applicable duty as applied by the courts.... is ultimately linked to ... the 'business judgment rule"); see also Kenneth B. Davis, Jr., Once More, the Business Judgment Rule, 2000 WIS. L. REV. 573, 573-76 \& n.1 (describing the elements of the business judgment rule as "(1) good-faith, (2) no self-dealing or self-interest, (3) an informed decision, and (4) a reasonable belief that the decision is in the best interest of the corporation").

91. See Unocal Corp. v. Mesa Petroleum Co., 493 A.2d 946, 954 (Del. 1985) ("A hallmark of the business judgment rule is that a court will not substitute its judgment for that of the board ...."); Hansen, supra note 90, at 1239-40 (stating that the "foundation stone" of corporate governance is the idea that "there must be a minimum of interference by the courts in internal corporate affairs").

92. See Aronson, 473 A.2d at 812 ("The business judgment rule is an acknowledgment of ... managerial prerogative[]."); see also Hansen, supra note 90, at 1239 (stating that there will be fewer directors willing to serve and "bold entrepreneurial decisions" will decrease if "directors are to be second-guessed as to the substance of their decisions"). See generally Davis, supra note 90 (discussing the business judgment rule in detail).

93. See Hansen, supra note 90, at 1239 ("The key point is that a director's legal duty of care cannot . . be measured by result. It should be measured only by process . . .."); see also Cramer v. Gen. Tel. \& Elecs. Corp., 582 F.2d 259, 274 (3d Cir. 1978) (noting that "[a]bsent bad faith ... directors are normally not liable to the corporation for mistakes of judgment").

94. Indeed, there are very few reported cases holding directors liable for a breach of their fiduciary duty outside of self-interested transactions. See Stuart R. Cohn, Demise of the Director's Duty of Care: Judicial Avoidance of Standards and Sanctions Through the Business Judgment Rule, 62 TEX. L. REv. 591, $591 \mathrm{nn} .1-2$ (1983) (finding only seven successful cases); see also Joseph W. Bishop, Jr., Sitting Ducks and Decoy Ducks: New Trends in the Indemnification of Corporate Directors and Officers, 77 YALE L.J. 1078, 1099 (1968) (finding only four successful shareholder cases); accord Henry Ridgely Horsey, The Duty of Care Component of the Delaware Business Judgment Rule, 19 DEL. J. CoRP. L. 971, 982 (1994) (affirming Bishop's study).

95. Smith v. Van Gorkom, 488 A.2d 858, 893 (Del. 1985) 
breaching their duty of care after finding that they had failed to make an informed business decision when they voted to approve a cash-out merger of their company. ${ }^{96}$ The court held the directors liable for $\$ 33.5$ million. ${ }^{97}$ The decision shocked the business community, particularly because the directors were precisely the kind of seasoned and sophisticated business people whose decisions appeared worthy of protection under the business judgment rule. ${ }^{98}$ This case appears to be the exception that proves the rule. ${ }^{99}$ As one scholar concludes, the business judgment rule serves as a "nearly insurmountable" barrier to director liability, with Van Gorkom standing out as the "one major instance in which nonconflicted managers were held liable to pay for their mismanagement."100 More importantly, in a recent study from 1968 to 2003 focusing on suits involving outside directors of public companies, Professors Bernard Black, Brian Cheffins, and Michael Klausner found that Van Gorkom was the only corporate-law case that imposed out-of-pocket liability on directors. ${ }^{101}$

\section{Id. at 862,893 .}

[W]e hold that the directors of Trans Union breached their fiduciary duty to their stockholders (1) by their failure to inform themselves of all information reasonably available to them and relevant to their decision to recommend the Pritzker merger; and (2) by their failure to disclose all material information such as a reasonable stockholder would consider important in deciding whether to approve the Pritzker offer.

Id.

97. See Sara R. Slaughter, Note, Statutory and Non-Statutory Responses to the Director and Officer Liability Insurance Crisis, 63 IND. L.J. 181, 184 (1987). The company's insurer paid the policy limit of ten million dollars, and the directors had personal responsibility for the remaining $\$ 23.5$ million. $I d$. However, the company's acquirer ultimately paid the bulk of the directors' remaining portion of liability. Id. at 184 n.21.

98. See Robert W. HAMilton \& Jonathan R. MACEY, CASES AND MATERIALS ON CORPORATIONS INCLUDING PARTNERSHIP AND LIMITED LIABILITY COMPANIES 830 (8th ed. 2003) ("The response of the corporate bar to Van Gorkom was one of shocked incredulity."); Michael Bradley \& Cindy A. Schipani, The Relevance of the Duty of Care Standard in Corporate Governance, 75 IowA L. REV. 1, 40 (1989) ("[T]he [Van Gorkom] decision came as a shock to the corporate community."); see also Van Gorkom, 488 A.2d at 894 (McNeilly, J., dissenting) (referring to the majority's decision as a "comedy of errors" and pointing out the extensive business experience of the directors as evidence that they deserved the protection of the business judgment rule).

99. In fact, Professors Margaret Blair and Lynn Stout argue that Van Gorkom is consistent with the rule because its ultimate effect was "to insulate directors from liability whenever they make even a modest attempt to follow the appropriate [procedural] formalities." Margaret M. Blair \& Lynn A. Stout, Trust, Trustworthiness, and the Behavioral Foundations of Corporate Law, 149 U. PA. L. REV. 1735, 1790 (2001).

100. Mark J. Roe, Corporate Law's Limits, 31 J. LeGAL Stud. 233, 243 (2002).

101. BERNARD BLACK ET AL., OUTSIDE DIRECTOR LIABILITY 6 \& tbl.I (Stan. L. \& Econ. Olin Working Paper No. 250, 2003), at http://ssrn.com/abstract=382422 (studying actual out-of-pocket liability rather than nominal liability). 
3. Exculpatory Statutes, Indemnification, and Insurance. Even if shareholder plaintiffs overcome the procedural hurdles necessary to get their day in court and convince the sitting judge to hold directors liable for breach of fiduciary duty by successfully rebutting the nearly insurmountable presumption of the business judgment rule, the combination of exculpatory statutes, indemnification provisions, and directors' and officers' ("D\&O") liability insurance-all of which are discussed below-means that such directors generally will not bear any out-of-pocket liability for their breach. ${ }^{102}$ In response to Van Gorkom, ${ }^{103}$ Delaware enacted Rule 102(b)(7), which allows a corporation to limit or eliminate personal liability for directors who breach their duty of care. ${ }^{104}$ Soon after, every state followed suit. ${ }^{105}$ These statutes are referred to as "exculpatory statutes." corporation's adoption of an exculpatory statute means that directors not only avoid financial liability for their misconduct but also are able to secure automatic dismissal of lawsuits in which shareholders' sole allegation is a duty of care violation. ${ }^{107}$

\section{Id. at 5 .}

103. See Cinerama, Inc. v. Technicolor, Inc., 663 A.2d 1156, 1166 n.18 (Del. 1995) (stating that Section 102(b)(7) was enacted in response to Van Gorkom); Bradley \& Schipani, supra note 98, at 43 (same); Model Bus. CORP. ACT ANN. § 2.02 cmt. 3(i) (2002) (noting that Van Gorkom and other developments highlighted the need for a limiting liability statute).

104. See DeL. CodE ANN. tit. 8, § 102(b)(7) (2001). Corporations can adopt such a provision in their charter. Id. This section does not enable corporations to limit or eliminate liability for breaches involving the duty of loyalty, the duty of good faith, the unlawful distribution of dividends, or transactions in which directors received an improper personal benefit. Id. The Model Business Corporation Act goes further than Delaware, allowing corporations to eliminate financial liability of directors except for financial benefits received by the director, intentional harm inflicted on the corporation or its shareholders, unlawful distributions, or intentional violations of criminal law. See MODEL Bus. CORP. ACT ANN. § 2.02(b)(4).

105. See J. Robert Brown, Jr., The Irrelevance of State Corporate Law in the Governance of Public Companies, 38 U. RICH. L. REV. 317, 332 n.93 (2004) (noting that by 2003 , all fifty states had statutes enabling corporations to limit or eliminate personal liability for directors); see also HAMILTON \& MACEY, supra note 98, at 832 (noting that as of January 1999, forty-three states had adopted similar statutes); Roberta Romano, Corporate Governance in the Aftermath of the Insurance Crisis, 39 EMORY L.J. 1155, 1160 (1990) (noting that within two years of Van Gorkom, forty-one states had adopted exculpatory statutes).

106. See, e.g., Hillary A. Sale, Delaware's Good Faith, 89 CoRnell L. REV. 456, 458 (2004).

107. See Malpiede v. Townson, 780 A.2d 1075, 1095-96 (Del. 2001) (noting that when a complaint exclusively alleges violations of the duty of care, it is dismissible once directors invoke the corporation's 102(b)(7) provision); Emerald Partners v. Berlin, 787 A.2d 85, 91 (Del. 2001) (noting that a claim is dismissible when the sole allegation relates to due care (citing Malpiede, 780 A.2d at 1093, 1095)). The Delaware Supreme Court has held recently that when a court has to conduct an entire fairness review because "the 
In so doing, these statutes not only severely reduce the threat of director liability, ${ }^{108}$ but also "minimize the opportunity for courts to patrol and reinforce the boundaries of business judgment."109

As a complement to exculpatory statutes, states also enable corporations to indemnify directors who are found liable for breaching the duty of care. ${ }^{110}$ Some states also enable corporations to make director indemnification mandatory, depriving corporations of the ability to pick and choose the kind of director breaches that will entail personal liability. ${ }^{111}$ In addition to indemnification for legal liability, most states require corporations to indemnify directors for reasonable expenses they incur in successfully defending against any proceeding brought against them based on their director status. ${ }^{12}$ Thus, indemnification provisions ensure that directors escape financial responsibility for any ultimate judgment as well as costs associated with litigating that judgment.

These provisions for indemnification combine with $\mathrm{D} \& \mathrm{O}$ insurance to solidify the virtual obliteration of director liability. All states allow corporations to purchase insurance on behalf of their directors and officers. ${ }^{113}$ Although public policy prohibits corporations from insuring against directors' willful conduct, ${ }^{114}$ states generally allow corporations to insure directors for actions even when corporations could not indemnify directors for those actions. ${ }^{115}$ Then too, the availability of D\&O insurance and

inherently interested nature of those transactions are inextricably intertwined with issues of loyalty" then an automatic dismissal is not appropriate, and instead the impact of the statute can only be considered after a determination of liability is made. See Emerald Partners, 787 A.2d at 92-94. For a discussion of the implications of this holding, see generally Stephen A. Radin, Director Protection Statutes and Motions to Dismiss After Emerald Partners, InSIGHTS: THE CORP. \& SEC. L. ADVISOR, June 1999, at 2, available at http://www.weil.com/wgm/pages/Controller.jsp?z=r\&sz=0 (last visited Apr. 24, 2005).

108. See Melvin A. Eisenberg, Corporate Law and Social Norms, 99 CoLUM. L. REv. 1253, 1267-68 (1999) (noting that the net effect of exculpatory statutes was to drastically reduce the threat of liability for directors who breach their duty of care).

109. Mae Kuykendall, Symmetry and Dissonance in Corporate Law: Perfecting the Exoneration of Directors, Corrupting Indemnification and Straining the Framework of Corporate Law, 1998 Colum. Bus. L. REV. 443, 479.

110. See, e.g., Model Bus. Corp. ACt ANN. § 2.02(b)(5) (2002); Bradley \& Schipani, supra note 98 , at 31 n.190 (citing statutes).

111. See, e.g., Model Bus. CoRP. ACT ANN. § 2.02(b)(5); Bradley \& Schipani, supra note 98 , at 31 \& nn.190-92 (citing statutes); see also Kuykendall, supra note 109, at 468 (discussing the formal linking of the standards for indemnification with the standards for exculpation from liability).

112. See Model Bus. Corp. Act AnN. § 8.52; Del. Code AnN. tit. 8, § 145(c) (2001).

113. See, e.g., Model Bus. CorP. ACt ANN. § 8.57; Del. Code ANn. tit. 8, § 145(a).

114. Bradley \& Schipani, supra note 98 , at 33 .

115. Id. at 32-33; see also Dennis J. Block et al., Indemnification and Insurance of Corporate Officials, 13 SEC. REG. L.J. 239, 250 (1985) (describing insurance coverage); 
indemnification are inextricably linked because most corporations can provide full indemnification only if they have liability insurance that covers those claims. ${ }^{116}$ The combination of indemnification provisions and D\&O insurance essentially eliminates directors' financial liability for breaching their fiduciary obligations. While insurance in other contexts has the similar effect of reducing an individual's financial liability for improper conduct, typically that individual must pay premiums and deductibles and thus does not completely escape liability. ${ }^{117}$ However, the corporate context differs from these other settings because the corporation-and not individual directors-bears responsibility for any deductibles and premiums related to that insurance. ${ }^{118}$ In this regard, directors truly appear to bear no costs for liability insurance and the conduct that it covers.

The aforementioned mechanisms result in directors operating in a regime of nearly complete exoneration for financial liability for breaches of their duty of care. ${ }^{119}$ This exoneration is reflected in the fact that prior to the most recent settlements, only one case existed in which directors had to pay out of their own pockets for their misconduct in their roles as directors. ${ }^{120}$ For this reason, corporate law appears to provide no significant legal mechanism for holding directors personally liable for the increased duties imposed upon them under Sarbanes-Oxley.

Marcia M. McMurray et al., Special Project, Protecting Corporate Directors and Officers: Insurance and Other Alternatives, 40 VAND. L. REV. 775, 783 (1987) (noting that D\&O insurance covers indemnification payments corporations must make as well as situations where the corporation cannot or will not indemnify a director).

116. See Slaughter, supra note 97, at 192 (pointing out that a "corporation runs the risk that the insurer will not reimburse the corporation for payments made according to expanded indemnity provisions").

117. See Peter F. Lake, The Special Relationship(s) Between a School and Student: Law and Policy Ramifications for the Post In Loco Parentis College, 37 IDAHO L. REv. 531, 542-43 (2001) (explaining that insurance law reflects the understanding that some personal accountability is required or people will "do some very uneconomic and stupid things").

118. See Bradley \& Schipani, supra note 98, at 32-33 (explaining that insurance enables corporations to cover directors who they would not have been able to indemnify).

119. See Blair \& Stout, supra note 99, at 1791 ("The net result is that, as a practical matter, a negligent director is more likely to be hit by lightning after leaving her board meeting than she is to pay damages."); Kuykendall, supra note 109, at 466 (labeling directors' formal insulation from liability under corporate law as the "exoneration canon").

120. See BLACK, supra note 101, at 6 \& tbl.I (pinpointing the absence of cases in this area). 


\section{Sarbanes-Oxley and Indirect Implications for Director Liability}

Although it seems relatively clear that the Sarbanes-Oxley legislators made no provisions for director liability, its requirements nonetheless could have some impact on director liability. This impact may occur at both the state and federal levels. ${ }^{121}$

1. Implications at the State Level. There are some indications that Sarbanes-Oxley may play a role in reversing the exoneration trend at the state level. ${ }^{122}$ Indeed, the passage of Sarbanes-Oxley has impacted the availability of D\&O insurance, ${ }^{123}$ which in turn may impact directors' exposure to financial liability. Directors' liability exposure increases if there is any reduction in D\&O insurance. During the 1980s and specifically after Van Gorkom, insurance premiums rose dramatically, and it was difficult for some corporations to secure D\&O insurance. ${ }^{124} \mathrm{~A}$ similar increase has occurred in the wake of the passage of Sarbanes-Oxley and litigation surrounding corporate governance scandals. ${ }^{125}$ As a result of these events, some of the largest commercial insurance companies have cut back on D\&O insurance by increasing deductibles and lowering limits on overall coverage. ${ }^{126}$ By reducing the availability of D\&O

121. See Johnson \& Sides, supra note 62, at 1209-12.

122. See, e.g., Renee M. Jones, Rethinking Corporate Federalism in the Era of Corporate Reform, 29 J. CORP. L. 625, 641-42 (2004); Sale, supra note 106, at 494-95

123. See Steven R. Smith, The Sarbanes-Oxley Act: How Will It Affect D\&O Insurance Coverage?, 91 ILL. B.J. 128, 129 (2003) (cautioning that since Sarbanes-Oxley was passed, "D\&O insurers are taking unprecedented steps to protect themselves against claims arising out of financial improprieties").

124. During the $1980 \mathrm{~s}$, the availability of $\mathrm{D} \& \mathrm{O}$ insurance was threatened by increased premiums, making such insurance more costly and decreasing substantive coverage. See Dennis J. Block et al., Advising Directors on the D\&O Insurance Crisis, 14 SEC. REG. L.J. 130, 130-31 (1986) (describing the D\&O insurance "crisis" and asserting that "[p]remiums are skyrocketing, deductibles are increasing at an extraordinary rate, coverage is shrinking, and more and more insurance companies are terminating their D\&O programs" (footnotes omitted)); Romano, supra note 105, at 1158-59 (noting the acute insurance crisis from 1985-1987, with some corporations experiencing premium increases exceeding 200\%); Slaughter, supra note 97, at 183-84 (discussing this crisis in insurance coverage). This crisis escalated after Van Gorkom. See Bradley \& Schipani, supra note 98, at 48 (noting that Van Gorkom was followed by unprecedented increases in D\&O premiums); Romano, supra note 105, at 1159 (stating that "[c]ourts also helped unsettle the D\&O market" in the 1980s).

125. See HAMILTON \& MACEY, supra note 98, at 1157 (noting the significant rise in premiums following the high profile corporate scandals of 2001 and 2002 and the passage of Sarbanes-Oxley).

126. Porcher L. Taylor III, Commentary, Danger for Directors: Sarbanes-Oxley Act May Have Diluted the Rule That Generally Bars Courts from Second-Guessing Board 
insurance coverage and simultaneously reducing the corporation's ability to provide meaningful indemnification, Sarbanes-Oxley may serve to increase directors' exposure to legal liability. Although relaxed liability exposure through exculpatory statutes reduces the need for D\&O insurance, ${ }^{127}$ and although high insurance premiums may eventually level off, SarbanesOxley has at least had a temporary impact on insurance and hence on director liability.

More significantly, there is evidence that Sarbanes-Oxley may play a role in increasing director liability by altering the manner in which state courts view exculpatory statutes. Recently, Delaware courts have allowed plaintiffs to use the duty of good faith to avoid both the application of section 102(b)(7) and a subsequent dismissal of any suit alleging breach of fiduciary duty. ${ }^{128}$ At least in Delaware, violations of the duty of good faith are not covered by the exculpatory statute. ${ }^{129}$ Thus, directors cannot rely on the statute to seek dismissal when such a violation is charged or to avoid personal liability when the

Decisions, 171 N.J. L.J. 1053, 1053 (2003).

127. Bradley \& Schipani, supra note 98 , at 57.

128. See In re Walt Disney Co. Derivative Litig., 825 A.2d 275, 286 (Del. Ch. 2003) (noting that allegations of lack of good faith fall outside of the exculpatory statute and hence defendants cannot use the statute to seek dismissal of these claims). In Emerald Partners $v$. Berlin, the Delaware Supreme Court maintained that when an entire fairness review was appropriate because of allegations related to a duty of loyalty breach, then plaintiffs could avoid dismissal. 787 A.2d 85, 93-94 (Del. 2001). The court also stated that lower courts had to probe the fairness of each of the directors' duties, including the duty of care, the duty of good faith, and the duty of loyalty. See id. at 97 (requiring boards to demonstrate fairness by "present[ing] evidence of the cumulative manner by which [they] discharge[] all [their] fiduciary duties"). Only after the court determined which of these duties had been violated could it determine the application of the exculpatory statute. Id. at 97-98. Although the Delaware Supreme Court later determined that it need not address the application of the statute because the price was fair and therefore directors were not liable for monetary damages, the court noted that there were "serious questions as to the independent directors' good faith." Emerald Partners v. Berlin, No. 295, 2003 WL 23019210, at*1 (Del. Dec. 23, 2003). The Delaware Supreme Court clearly seemed to predicate its discussion on duty of loyalty violations. See Emerald Partners, 787 A.2d at 94,97 . However, by requiring courts to review duty of good faith violations once duty of loyalty violations are established, the court opens the door to two possibilities: First, the duty of good faith violations will receive heightened, more rigorous review, increasing the potential that directors will be held liable for such violations. Second, courts will hold directors liable for breaching their duty of good faith without finding that directors violated the duty of loyalty. The ultimate result could be that with strong duty of loyalty allegations, plaintiffs are enabled to make an end-run not only around Delaware's exculpatory statute, but also around the business judgment rule's application to their duty of good faith claims. In this respect, the Delaware Supreme Court may have paved the way for increased financial liability based on the directors' duty of good faith.

129. See Del. CodE ANN. tit. 8, § 102(b)(7) (2001). In contrast, the Model Business Corporation Act does not have an exemption for the duty of good faith. See MoDEL Bus. CORP. ACT § 2.02(b)(4) (1999). 
violation is proven. ${ }^{130}$ Delaware courts, particularly the one involved in the Walt Disney Corporation ("Walt Disney") dispute, have suggested that the fiduciary duty of good faith encompasses a duty to remain informed and to ask appropriate questions of corporate officers. ${ }^{131}$ This redefined duty of good faith appears to include the obligations directors must satisfy under SarbanesOxley. ${ }^{132}$ Thus, by essentially recharacterizing duty of care claims as breaches of the duty of good faith, Delaware courts may have discovered a way to impose financial liability on directors who breach their fiduciary duty of attention and inquiry. ${ }^{133}$ Of course, if directors are held liable for violating their duty of good faith, they can seek indemnification for such liability ${ }^{134}$ or, if that fails, apply for coverage under their corporation's D\&O insurance. ${ }^{135}$ However, directors may not be able to secure full coverage if courts subject them to significant liability. ${ }^{136}$ Indeed, as occurred in Van Gorkom, the amount of the liability may exceed the maximum insurance coverage amounts, leaving directors to pay the remainder. ${ }^{137}$ This is because as directors' liability and risk of liability increase, the cost of insurance should increase, perhaps making insurance prohibitive for some corporations. ${ }^{138}$ As the previous paragraph reveals, such increased cost may represent a post-Enron reality. Thus, despite the availability of insurance and indemnification, if courts can impose financial liability on directors through the good faith exception, then there is a strong

130. See Del. Code ANN. tit. 8, § 102(b)(7).

131. See Walt Disney, 825 A.2d at 287-89 (noting the failure of directors to pay attention, ask questions, and review documents during board meetings). Appearing to approve this characterization of a lack of good faith, the Delaware Supreme Court cited Walt Disney for the proposition that courts should not condone lax behavior and a "we don't care about the risks" attitude. Emerald Partners, No. 295, 2003 WL 23019210, at *1 (Del. Dec. 23, 2003) (citing Walt Disney, 825 A.2d at 289).

132. See supra Part II (discussing standards of conduct imposed by Sarbanes-Oxley).

133. Although the Delaware Chancery Court was careful to emphasize that the plaintiff shareholders had alleged sufficient facts for a breach of the "obligation to act honestly and in good faith," the allegations, including that the directors lacked due care in the decisionmaking process, appear remarkably similar to duty of care claims. See Walt Disney, 825 A.2d at 287-89; see also Smith v. Van Gorkom, 488 A.2d 858, 875 (Del. 1985) (noting that due care includes a reasonable deliberation when making decisions).

134. See supra Part III.B.3 (discussing how directors can avoid liability by seeking indemnification)

135. See supra Part III.B.3 (discussing the potential of D\&O insurance to completely eliminate directors' financial responsibility).

136. See supra notes $123-27$ and accompanying text (describing the impact that Sarbanes-Oxley has had on D\&O insurance).

137. See supra note 97 (explaining Van Gorkom directors' individual responsibility for damage payments after exhausting corporate insurance).

138. See supra notes 123-24 and accompanying text (explaining increases in D\&O insurance caused by Sarbanes-Oxley). 
likelihood that directors will bear some personal responsibility for that liability. ${ }^{139}$

It is noteworthy that Sarbanes-Oxley may have spurred Delaware's new stance on exculpatory statutes and director liability. The mere fact that the Delaware cases enunciating this new stance were decided post Enron and post Sarbanes-Oxley may indicate that those events had some impact on the courts' decisions. ${ }^{140}$ But there is more. Indeed, shareholders filed their suit against Walt Disney in January 1997, and the case was initially dismissed by the Delaware Chancery Court. ${ }^{141}$ However, when plaintiffs refiled the suit in January 2002, post Enron and Sarbanes-Oxley, the Delaware Chancery Court appeared to do an about-face. ${ }^{142}$ The court not only showed a willingness to find breaches of the directors' fiduciary duty, ${ }^{143}$ but also found a way to avoid exoneration by basing allegations related to the breaches on the duty of good faith. ${ }^{144}$ More importantly, the Delaware Supreme Court later cited the Walt Disney decision with approval. ${ }^{145}$ Former Delaware Chancery Court judge William Allen confirmed the impact that Enron and Sarbanes-Oxley had on Delaware courts' willingness to increase directors' liability in order to ensure greater adherence to directors' fiduciary responsibilities. ${ }^{146}$ Commenting on the Walt Disney decision, he noted, "It would not be unreasonable to assume that the Delaware courts are responding to the Enron and WorldCom headlines and the intrusion, so to speak, of the federal government into the internal governance of corporations." ${ }^{147}$ Put

139. See Eisenberg, supra note 108, at 1267-68 (noting that the interpretation of the good faith exception diminishes the protective shield of exculpatory statutes).

140. For example, while Congress passed Sarbanes-Oxley in 2002, both Emerald Partners and Walt Disney were decided in 2003. See generally Sarbanes-Oxley Act of 2002, Pub. L. No. 107-204, 116 Stat. 745 (codified in scattered sections of titles 11, 15, 18, 28, and 29 of the U.S.C.); Emerald Partners v. Berlin, 787 A.2d 85 (Del. 2003); In re Walt Disney Co. Derivative Litig., 825 A.2d 275 (Del. Ch. 2003).

141. See Gunther, supra note 63 , at 176 (noting that few people took notice of the case when it was filed, during a time when "Enron was a hot stock, corporate governance was a snooze, and no one outside Maryland or Ohio knew Sarbanes or Oxley").

142. See id. (commenting that "[c]learly, the climate in Delaware has changed").

143. See Walt Disney, 825 A.2d at 278 (concluding "that plaintiffs' new complaint sufficiently pleads a breach of fiduciary duty ... so as to withstand [defendants'] motion to dismiss").

144. See id. at 289 ("Viewed in this light, plaintiffs' new complaint sufficiently alleges a breach of the directors' obligation to act . . . in good faith ....").

145. See Emerald Partners v. Berlin, No. 295, 2003 WL 23019210, at*1 n.4 (Del. Dec. 23, 2003) (quoting Walt Disney's "we don't care about the risk" standard).

146. See Gunther, supra note 63, at 176 (discussing Allen's theories of post-Enron changes in director liability).

147. Id. (quoting former Chancellor William Allen). 
another way, by the time Walt Disney shareholders refiled their suit, Sarbanes-Oxley "had put Delaware on the defensive. If the state was perceived to be doing a less-than-rigorous job of protecting shareholders, the federal government might take more responsibility for corporate law, thereby eroding Delaware's power." ${ }^{\text {"148 }}$ Hence, Sarbanes-Oxley may have caused the Delaware state courts to reverse the exoneration trend. ${ }^{149}$

Of course, whether these hints of reversal will coalesce into something more remains an open question. Indeed, Delaware judges have relied on the good faith carve-out embedded in section $102(b)(7)$ as a foundation for this reversal. ${ }^{150}$ However, other judges appear to question this reliance, strongly disagreeing with the proposition that the duty of good faith represents an independent fiduciary duty. ${ }^{151}$ One Delaware Chancery Court judge has pointed out, "in my view and the view of other members of this Court," the way that section 102(b)(7) is drafted "balkanizes the fiduciary duty of loyalty" and creates the confusing idea that the duty of good faith constitutes an independent duty. ${ }^{152}$ If this view represents the more dominant one, then most Delaware courts will continue interpreting exculpatory statutes in a manner that shields directors from legal liability. Other judges have urged the Delaware legislature to take action, stating that "[t]he [Delaware] General Assembly could contribute usefully to ending the balkanization of the duty of loyalty by rewriting $\S 102(b)(7)$ to make clear that its subparts all illustrate conduct that is disloyal."153 Such a rewrite would ensure that the duty of good faith could not be used as a basis for challenging conduct representing a breach of a director's duty of care, thereby reaffirming the strength of Delaware's exculpatory statute in shielding directors from financial liability based on

148. Id.

149. See generally Jones, supra note 122, at 629 (illustrating how Sarbanes-Oxley has influenced Delaware courts in their move toward a stricter enforcement of fiduciary duties); Sale, supra note 106, at 494-95 (suggesting the same).

150. In re Walt Disney Co. Derivative Litig., 825 A.2d 275, 286 (2003) (analyzing the good faith "protective ambit" provided by section 102(b)(7)).

151. See Guttman v. Huang, 823 A.2d 492, 506 n.34 (Del. Ch. 2003) (noting that the duty of good faith is not an independent fiduciary duty); Emerald Partners v. Berlin, No. Civ.A. 9700, 2003 WL 21003437, at *39 n.133 (Del. Ch. Apr. 28, 2003) (same), affd 840 A.2d 641 (Del. 2003). The notion that the duty of good faith is a separate fiduciary duty stems not merely from section 102(b)(7), but also from a 1993 Delaware Supreme Court decision, which enunciated a "triad" of directors' fiduciary duties, containing the duty of good faith, loyalty, and due care. Cede \& Co. v. Technicolor, Inc., 634 A.2d 345, 361 (Del. 1993).

152. Emerald Partners, 2003 WL 21003437, at *39 n.133.

153. Guttman, 823 A.2d at 506 n.34. 
such a breach. Certainly, the Delaware legislature is free to alter the statute, and based on its swift implementation of section 102(b)(7) after Van Gorkom, ${ }^{154}$ one may expect such an alteration to occur-if court decisions indicate real potential for director liability. And an alteration may occur all the more swiftly given the apparent support of Delaware judges.

Notably, the Model Business Corporation Act does not have an exemption for the duty of good faith. ${ }^{155}$ Thus, states that have adopted some version of that Act do not even have the good faith exemption on which to rely. In this respect, the Delaware legislature already has a model to follow for eliminating the good faith exemption, and elimination appears to have the support of several Delaware judges. ${ }^{156}$ These facts suggest viewing with caution the state level trend of undermining the shield against director liability.

2. Implications at the Federal Level. Possibly more promising is the impact that Sarbanes-Oxley may have at the federal level. Indeed, a careful analysis of Sarbanes-Oxley reveals that it could have an indirect impact on the ability of shareholders to hold directors personally liable under federal securities laws. Although one cannot bring a federal securities law claim against directors based on a breach of their fiduciary duty, ${ }^{157}$ there are some circumstances under which federal securities laws subject directors to liability for failing to perform their responsibilities as directors adequately. And although imposing liability on directors for this failure has proved difficult in the past, Sarbanes-Oxley may enable plaintiffs to overcome this difficulty.

Indeed, federal law appears to expose directors to liability for failing to carry out their monitoring duties. Directors can be held liable for securities fraud if they sign their corporation's annual report with knowledge of its inaccuracies. ${ }^{158}$ Similarly,

154. See supra notes 103-04 and accompanying text (explaining enactment of section 102(b)(7) as a response to Van Gorkom and the insurance crisis).

155. See MODEL Bus. CORP. ACT ANN. § 2.02(b)(4) (2002).

156. See supra notes 145-47 and accompanying text (noting the responses of various members or former members of the judiciary).

157. See, e.g., Santa Fe Indus., Inc. v. Green, 430 U.S. 462, 474-75 (1977) (finding a breach of fiduciary duty claim insufficient for a securities fraud action); Cort v. Ash, 422 U.S. 66, 82-84 (1975) (explaining reluctance to imply a federal cause of action when state law governs directors' responsibilities).

158. See generally Fairfax, supra note 21, at 18-20 (explaining director and officer liability for signing annual reports). Indeed, the Ninth Circuit has held that a corporate officer who knowingly signs an inaccurate financial statement can be held liable for securities fraud. See Howard v. Everex Sys., Inc., 228 F.3d 1057, 1061-63 (9th Cir. 2000); 
liability can be imposed on directors for their role in the corporation's fraud either as the primary perpetrator of the fraud ${ }^{159}$ or for controlling an entity found liable for such fraud. ${ }^{160}$ These kinds of claims implicate the role of directors as corporate fiduciaries because this type of violation suggests a failure to monitor the corporation appropriately. For example, to hold a director liable for signing a fraudulent annual report, plaintiffs must either prove that the director signed the document despite knowledge of its fraudulent contents or that the director signed the document with a reckless disregard of its fraudulent nature by ignoring red flags. ${ }^{161}$ Similarly, securities fraud actions seeking to hold a director liable as a primary violator must demonstrate that the director either participated in the fraud or knew or should have known about the fraud and recklessly disregarded its implications. ${ }^{162}$ Finally, directors may be subject to control-person liability only if proven that they knew or should have known of the existence of fraud within their corporation. ${ }^{163}$ Because violations can be established by showing that directors

see also Christian J. Mixter, Individual Civil Liability Under the Federal Securities Laws for Misstatements in Corporate SEC Filings, 56 Bus. LAW. 967, 969-70 (2001) (discussing the impact of Howard on directors and officers).

159. Section 10(b) of the Securities Exchange Act of 1934 ("Exchange Act"), as amended, and Rule 10b-5 provide that any person can be held liable for making a material misstatement in connection with a securities transaction. Securities Exchange Act of 1934, 15 U.S.C. $§ 78 \mathrm{j}$ (2000); Commodity and Securities Exchanges, 17 C.F.R. $\S 240.10 b-5$ (2004). In Central Bank of Denver v. First Interstate Bank of Denver, 511 U.S. 164, 188-91 (1994), the Supreme Court held that aiders and abettors could not be subject to liability under Section 10(b) and Rule 10b-5. Id. at 191. Instead, only a primary violator of those provisions could be held liable for securities fraud. Id.

160. Section 20(a) of the Exchange Act imposes joint and several liability on "every person who, directly or indirectly, controls any person"-including corporate and government entities. 15 U.S.C. $\S \S 78 \mathrm{t}(\mathrm{a}), 78 \mathrm{c}(\mathrm{a})(9)$.

161. See Fairfax, supra note 21, at 25-26 \& n.114 (citing cases supporting the position that "officers can be held liable for signing inaccurate Exchange Act reports with knowledge of the inaccuracy").

162. See id. at 51-54 (describing the required proof of scienter for securities fraud violations).

163. Section 20(a) of the Exchange Act provides an affirmative defense for those control persons who "acted in good faith and did not directly or indirectly induce the act or acts constituting the violation or cause of action." 15 U.S.C \& 78t(a). Courts have construed this provision to require that directors did not know or should not have known of fraudulent activities. See, e.g., Lanza v. Drexel \& Co., 479 F.2d 1277, 1302-06 (2d Cir. 1973) (holding that a director is not liable as a control person unless he willfully or recklessly disregarded the truth); Mader v. Armel, 461 F.2d 1123, 1125-26 (6th Cir. 1972) (recognizing that a defendant is not liable as a controlling person without evidence that he knew or should have known of wrongdoing); Hamilton Bank \& Trust Co. v. Holliday, 469 F. Supp. 1229, 1243 (N.D. Ga. 1979) (noting that lack of knowledge of misrepresentations exempts directors from liability as controlling person); Ingenito $\mathrm{v}$. Bermec Corp., 441 F. Supp. 525, 533 (S.D.N.Y. 1977) (noting the importance of knowledge to the affirmative defense for control persons). 
ignored or disregarded red flags, each of these claims implicate directors' obligations to remain informed and ask probing questions about their corporation's financial affairs: If it can be shown that directors should have been aware of fraudulent activities related to particular corporate transactions because they had responsibility for knowing about the transactions, then they can be subject to various federal securities law violations. In this way, securities law violations implicate directors' monitoring duties.

However, securities fraud suits in this area have been unsuccessful because of the difficulty of proving that directors had the requisite knowledge to be held liable. ${ }^{164}$ As the preceding paragraph demonstrates, actual or constructive knowledge presents a critical component of federal securities claims involving director violations. Regarding accounting fraud, for example, a plaintiff must prove that a director knew or should have known of the accounting violations related to a specific transaction and that the director knew or disregarded clear signals that those violations represented a material misstatement of the transaction. ${ }^{165}$ However, establishing this kind of knowledge represents an almost insurmountable hurdle because directors are usually not involved in the day-to-day affairs of the corporation and thus are often unaware of specific transactions and their implications. ${ }^{166}$ Then too, in cases

164. In addition to the difficulties of proving intent, heightened pleading rules in civil cases also make it difficult to bring actions against directors because the Private Securities Litigation Reform Act of 1995, Pub. L. No. 104-67, 109 Stat. 737 (codified at 15 U.S.C. $\S 78 u-4(2000)$ ), requires that plaintiffs allege "with particularity facts giving rise to a strong inference that the defendant acted with the required state of mind." 15 U.S.C. $\S 78 u-4(b)(2)$ (2000). Plaintiffs have found this to be a difficult requirement to meet. See, e.g., Gompper v. VISX, Inc., 298 F.3d 893, 895-98 (9th Cir. 2002) (finding that plaintiff's complaint, though it contained facts from which scienter could be inferred, did not meet the threshold imposed by Congress); Ronconi v. Larkin, 253 F.3d 423, 429-32 (9th Cir. 2001) (holding plaintiff failed to allege "specific "contemporaneous statements or conditions" that would give rise to the "strong inference" of scienter necessary to sustain a claim under 15 U.S.C. $\$ 78(\mathrm{u})-4(\mathrm{~b})(2)$ (citations omitted)).

165. See, e.g., In re Fine Host Corp. Sec. Litig., 25 F. Supp. 2d 61, 69 (D. Conn. 1998) (requiring a complaint involving accounting fraud to allege that the defendant was aware of false or misleading numbers and that she "deliberately avoided checking into the numbers because she suspected them to be false or misleading").

166. See Elizabeth Amon, White Collar Crime: Heat Going Up? It's Tough to Prosecute CEOs-For Now, NAT'L L.J., July 8, 2002, at A15 (citing Assistant U.S. Attorney and chief of New Jersey's Securities Fraud Unit John Carrey as noting that "often there are a few e-mails or memos that can prove a CEO [had] knowledge about illegal accounting practices"); Jennifer Arlen, Commentary, Forget New Laws-Fix the Old Ones, L.A. Times, July 10, 2002, at B13 (noting that "[i]t is very difficult to prove ... intent to defraud"); Jim Oliphant, Throwing CEOs in Jail No Easy Job, LEGAL TIMES, July 15, 2002, at 1, 14 (noting that "the higher up someone is, the harder it is to charge them" because they are "often removed from the day-to-day operations" of their 
involving financial fraud, such as Enron, establishing director knowledge proves challenging because violations are often buried in complex financial statements. ${ }^{167}$ For this reason, it is very rare for directors to face personal liability under federal securities laws. In fact, case law suggests that such liability cannot be imposed unless directors have a duty to monitor specific transactions and hence a duty to be aware of misleading information regarding those transactions. ${ }^{168}$ Thus, in their most recent study, Professors Black, Cheffins, and Klausner found no federal securities cases in which outside directors were held personally liable. ${ }^{169}$

Sarbanes-Oxley imposes specific duties to monitor various transactions and thus may increase the ability of plaintiffs to hold directors liable under federal securities laws. ${ }^{170}$ First, directors who serve on the audit committee of their corporation should have greater awareness about the financial affairs of the corporation because they not only have primary responsibility for the flow of financial information, but also must oversee disagreements related to that information and employee complaints regarding accounting and auditing irregularities. ${ }^{171}$ Second, these audit committee directors should also have a heightened awareness of any accounting and auditing irregularities because they must receive reports about significant defects in the internal control procedures. ${ }^{172}$ Finally, depending on the procedure that the specific corporation adopts, either the directors who serve on the QLCC or the entire board should know about evidence related to material securities fraud or fiduciary duty violations. ${ }^{173}$ Thus, Sarbanes-Oxley specifically ensures that

companies)

167. See Arianne Lavell et al., Payback Time? Seeking Retribution for Enron's Losses Won't Be Easy, U.S. NEWs \& WORLD REP., Mar. 11, 2002, at 36 (quoting a former federal prosecutor who explains that proof of fraud is often "buried in documents-sometimes hundreds of thousands of documents").

168. See, e.g., In re Xerox Corp. Sec. Litig., 165 F. Supp. 2d 208, 215-16 (D. Conn. 2001) (noting that recklessness can be demonstrated by showing that a defendant "failed to review or check information that they had a duty to monitor, or ignored obvious signs of fraud").

169. BLACK ET AL., supra note 101, at 34.

170. See supra Part II (discussing how Sarbanes-Oxley appears to federalize directors' fiduciary duty to closely monitor audits).

171. See supra text accompanying notes 34-35 (discussing how Sarbanes-Oxley imposes responsibilities on directors to oversee and remain informed about auditor's financial work and related disagreement).

172. See supra text accompanying note 41.

173. See supra notes 45-57 and accompanying text (explaining that under SarbanesOxley the corporation's entire board or QLCC receives evidence of securities fraud or fiduciary duty breaches from attorneys appearing or practicing before the SEC). 
the board or the audit committee should be made aware of illegal behavior as well as evidence that might establish illegal behavior. By increasing directors' obligations in these various ways, Sarbanes-Oxley increases our expectations about their general and specific knowledge of corporate affairs and misconduct. These increased expectations may make it harder for directors to deny awareness of financial irregularities in reports they sign or companies they oversee. Even when directors have no actual knowledge of irregularities, Sarbanes-Oxley implies that they should. In this respect, Sarbanes-Oxley may increase the chances of directors being held personally liable under federal law for failing to remain properly informed.

Then too, similar to its impact at the state level, SarbanesOxley and the general dissatisfaction with director conduct that it symbolizes may give shareholders the political clout they need to ensure that directors face personal liability in federal securities class-action settlements. Indeed, prior to Enron, directors rarely faced personal liability even when shareholder class-action suits were settled for monetary damages. ${ }^{174}$ Instead, insurance most often served to insulate directors from liability. However, directors at Enron and WorldCom recently agreed to be personally liable for portions of shareholder settlements: ${ }^{175} \mathrm{~A}$ group of former Enron directors agreed to pay $\$ 13$ million of their own money in connection with a $\$ 168$ million settlement, and ten former directors of WorldCom agreed to pay $\$ 18$ million of their own money as part of a $\$ 54$ million settlement. ${ }^{176}$ It is noteworthy that directors agreed to these settlements despite the fact that judges had already dismissed shareholder suits against them because of their lack of requisite intent under federal securities laws. ${ }^{177}$ Shareholders' insistence that directors remain part of the settlement suggests their desire to hold these directors

\footnotetext{
174. See BLACK ET AL., supra note 101, at 2 (noting prior to the Enron and WorldCom settlements that "[t]o our knowledge, no outside director of a public company has paid out-of-pocket for either damages or legal expenses under securities law, ever"). In their study, Professors Black, Cheffins, and Klausner reviewed cases involving outside directors of public companies from 1968 to the present and found no cases in which actual liability had been imposed. $I d$. In the few securities cases in which directors paid modest settlement fees, the directors were indemnified. See id. at 6 .

175. See White, supra note 4.

176. Id.

177. See Kurt Eichenwald, Enron's Outside Directors Win a Round in Court, N.Y. TiMES, Mar. 14, 2003, at C6 (reporting that the case was dismissed because "the plaintiffs failed to demonstrate that the board members knew about any wrongdoing"); see also In re Enron Corp. Sec., Derivative \& ERISA Litig., 258 F. Supp. 2d 576, 624, 627, 649 (S.D. Tex. 2003) (dismissing claims against directors).
} 
personally accountable, ${ }^{178}$ while directors' willingness to face such personal liability may reflect an increased federal pressure to obtain better director accountability embodied at least in the spirit of Sarbanes-Oxley.

This increase in the potential for director liability at the federal level is especially significant given the greater certainty and severity of penalties in this area. Indeed, Sarbanes-Oxley increased the penalties for violations of securities fraud from ten to twenty years in prison and from one to five million dollars in fines. ${ }^{179}$ Moreover, the Federal Sentencing Guidelines (the "Guidelines") ensure that when directors are found liable for such transgressions, they will be required to serve at least a minimum prison sentence and to pay a criminal fine. ${ }^{180}$ With respect to financial liability, the SEC has taken the position that states cannot indemnify directors for violations of federal securities laws. ${ }^{181}$ Courts stress that such a position reflects the SEC's view that indemnification will undermine the deterrence goals of federal securities laws. ${ }^{182}$ Then too, because it is a federal claim, state exculpatory statutes are inapplicable. ${ }^{183}$ Thus, even though

178. See White, supra note 4 (reporting that a WorldCom shareholder desired to hold directors personally liable to send a deterrent message).

179. See Sarbanes-Oxley Act $§ 1106,15$ U.S.C. § 78ff(a) (Supp. II 2002).

180. See Geraldine Szott Moohr, An Enron Lesson: The Modest Role of Criminal Law in Preventing Corporate Crime, 55 FLA. L. REV. 937, 941-42 (2003) (describing the impact of federal sentencing guidelines on white collar criminal penalties). In an apparent reversal of its earlier decision upholding the constitutionality of the Guidelines, see Mistretta v. United States, 488 U.S. 361, 374, 389-91, 398-99, 412 (1989), the Supreme Court has recently called into question the constitutionality of the Guidelines, see Blakely v. Washington, 124 S. Ct. 2531, 2538 \& n.9 (2004) (declaring Washington State's sentencing guidelines unconstitutional but refusing to discuss the similar Federal Sentencing Guidelines). This could have significant repercussions for both the severity and certainty of all federal sentences.

181. See Commodity and Security Exchanges, 17 C.F.R. $\$ \S 229.510,229.512(\mathrm{~h})(3)$ (2000) (explaining how the indemnification of directors for liability arising under the Securities Act "is against public policy ... and is therefore unenforceable"). While this position is expressed in connection with the Securities Act, it has been interpreted to apply to the Exchange Act as well. See Heizer Corp. v. Ross, 601 F.2d 330, 334-35 (7th Cir. 1979) (expanding the SEC position against indemnification to section 10(b) of the Exchange Act). In addition, most cases agree with the SEC's position. See Ross, 601 F.2d at 334 (noting that several courts have held that indemnification is not available in securities cases); see also JOSEPH WARREN BISHOP, JR., THE LAW OF CORPORATE OFFICERS AND DIRECTORS: INDEMNIFICATION AND INSURANCE § 6.16 (Supp. 2004); Alan Applebaum \& Robert A. McDowell, Indemnification Against Securities Acts Liabilities, 27 BUS. LAW. 131, 134, 137 (1972); David B. Schulz, Indemnification of Directors and Officers Against Liabilities Imposed Under Federal Securities Laws, 78 MARQ. L. REV. 1043, 1057-58 (1995).

182. See Globus v. Law Research Serv., Inc., 418 F.2d 1276, 1288 (2d Cir. 1969) (observing "that to tolerate indemnity... would encourage flouting the policy of the common law and the Securities Act").

183. See Frank Balotti \& Mark Gentile, Elimination of Limitation of Director 
their behavior appears similar to a violation of fiduciary law, directors cannot make use of many of the state mechanisms that shield them from personal liability. In this respect, SarbanesOxley's federalization of fiduciary duties and the liability associated therewith may represent a significant departure from the exoneration trend.

And yet there is reason for skepticism about the completeness of this departure. Indeed, while the SEC appears hostile to corporate indemnification efforts, the SEC has not expressed a similar hostility towards D\&O insurance. ${ }^{184}$ Thus, corporations can continue to shield directors from liability through such insurance. The strength of this shield may depend on shareholders' individual efforts. Indeed, although insurance proceeds were used to pay some portion of the Enron and WorldCom settlements, both settlement agreements apparently were structured so that the insurance liability was exhausted; hence, directors were forced to bear some personal liability. ${ }^{185} \mathrm{It}$ is too soon to determine if shareholders will continue to ensure that directors do not take advantage of insurance. More importantly, the Supreme Court has indicated a reluctance to hold corporate officials federally liable for actions that essentially amount to breach of fiduciary duty claims. ${ }^{186}$ According to the Court, "Corporations are creatures of state law, and investors commit their funds to corporate directors on the understanding that, except where federal law expressly requires certain responsibilities of directors with respect to stockholders, state law will govern the internal affairs of the corporation."187 Certainly, Sarbanes-Oxley does impose express responsibilities on directors ${ }^{188}$ and thus, consistent with the Supreme Court's pronouncement, suggests that courts should provide some federal

Liability for Delaware Corporations, 12 DEL. J. CoRP. LAW 5, 13 (1987) (noting that section 102(b)(7) of the Delaware General Corporation statute excludes violations for state or federal securities laws).

184. Rule 461(c) of the Securities Act provides that "[i]nsurance against liabilities arising under the [Securities] Act, whether the cost of insurance is borne by the registrant, the insured or some other person, will not be considered a bar to acceleration ....” 17 C.F.R. § 230.461(c) (2004).

185. See White, supra note 4 (discussing the details of the settlements).

186. See Cort v. Ash, 422 U.S. 66, 84-85 (1975) (noting that a cause of action for breach of fiduciary duty may arise out of a federal law violation depending on the state law that governs corporate internal affairs and further stating that "[w]e are necessarily reluctant to imply a federal right to recover funds used in violation of a federal statute where the laws governing the corporation may put a shareholder on notice that there may be no such recovery").

187. Id. at 84 (emphasis added).

188. See supra notes $64-71$ and accompanying text (discussing the requirements that sections 305 and 306 of the Sarbanes-Oxley Act impose upon directors). 
remedy for breaches of those responsibilities. However, Sarbanes-Oxley's failure to provide some express remedy for directors' violations of their responsibilities may be viewed as a signal of Congress's intention to leave any remedy to state law. That signal may be supported by the fact that Congress has provided an express remedy for officers who violate their new responsibilities. ${ }^{189}$ In this regard, Congress's failure to impose some specific liability on directors, when viewed in contrast with their treatment of CEOs and CFOs, may undermine efforts to hold directors liable at the federal level by suggesting that Congress did not intend such liability to be conferred under federal law.

Ultimately, therefore, it is unclear whether indirect measures at the state and federal level will increase the possibility that directors face legal liability for failing to perform their fiduciary responsibilities under Sarbanes-Oxley. Certainly, given the Act's apparent purposeful exclusion of director liability, if any such increase arises, it probably will be unintentional. Moreover, there remains uncertainty regarding whether these indirect measures will prove sufficient to undermine the shield protecting directors from legal liability. In this regard, SarbanesOxley's failure to contain a provision specifically imposing legal liability on directors may ensure a continuation of the status quo. The next Part will address the consequences of such continuation.

\section{THE CONSEQUENCES OF SPARING THE ROD ON DIRECTOR BEHAVIOR}

If Sarbanes-Oxley does not open the door to imposing liability on corporate directors, what difference does it make on directors' fidelity to their obligations? Many corporate scholars would argue that it makes very little difference ${ }^{190}$ and hence would view with approval Sarbanes-Oxley's reiteration of the status quo with respect to director liability. This Part examines the primary arguments against director liability. On the one hand, some scholars argue that legal sanctions may be neither necessary (because of extra-legal factors that shape director conduct) nor effective in constraining director behavior. ${ }^{191}$ On the other hand, even scholars who do not negate the impact of legal

189. See supra notes $72-76$ and accompanying text (citing the penalties that the Sarbanes-Oxley Act imposes upon officers who breach their duty).

190. See infra notes 193, 195 (questioning deterrence value of legal penalties).

191. See infra Part III.A. 
sanctions argue that we should prefer extra-legal sanctions because the cost of legal liability is too high. ${ }^{192}$ This Part demonstrates the defects in these arguments, suggesting several reasons why we should be wary of Sarbanes-Oxley's apparent refusal to impose legal liability on directors.

\section{A. . . Ashes, Ashes, They All Fall Down: The Failings of Extra-Legal Measures}

Many scholars maintain that legal sanctions are not necessary to regulate director conduct because other extra-legal forces ensure that directors comply with their fiduciary obligations. ${ }^{193}$ Specifically, both reputational sanctions and the capital market pressure directors to act in the best interests of the corporation and its shareholders. ${ }^{194}$ Of course, the very existence of Enron and other corporate scandals reveals the imperfections in the ability of these external measures to prevent director irresponsibility. These imperfections in turn undermine the rationale for rejecting legal sanctions as a means of shaping director behavior.

First, many scholars insist that we need not impose legal sanctions on directors because their desire to maintain a positive reputation encourages them to perform their fiduciary responsibilities with the appropriate level of diligence. ${ }^{195}$ Board members, particularly outside board members, often hold prestigious positions within their respective business, government, and academic communities. For example, the chair of Enron's audit committee was a professor emeritus of

192. See infra Part III.B.

193. See David M. Phillips, Principles of Corporate Governance: A Critique of Part IV, 52 GEO. WASH. L. REV. 653, 673 (1984) (noting that extra-legal incentives regulate conduct and make legal regulation undesirable); see also BLACK ET AL., supra note 101, at 43, 48 (pointing to other extra-legal incentives that regulate director conduct including monitoring by D\&O insurers and directors' sense of professionalism).

194. See BLACK ET AL., supra note 101, at 44-48 (noting that concern for their reputation represents a key element of directors' incentives to perform their duties appropriately); Phillips, supra note 193, at 673-83 (suggesting that the market affects corporate behavior).

195. See John C. Coffee, Jr., Understanding the Plaintiff's Attorney: The Implications of Economic Theory for Private Enforcement of Law Through Class and Derivative Actions, 86 COLUM. L. REV. 669, 718 (1986) (noting that even without sanctions, settlements do significant damage to reputations, and the fear of such damage constrains director behavior); Eisenberg, supra note 108, at 1265 (noting that directors' adherence to their duty of care is driven largely by social norms, which depends on reputation, rather than the threat of liability); see also Frank H. Easterbrook \& Daniel R. Fischel, Mandatory Disclosure and the Protection of Investors, 70 VA. L. REV. 669, 675 (1984) (discussing the reputation concerns of managers, promoters, accountants, and investment bankers in disclosure situations). 
accounting and the former dean of the Stanford University Graduate School of Business. ${ }^{196}$ Other outside directors included three CEOs of corporations, one president and one former president of M.D. Anderson Cancer Center, and a former U.K. Secretary of State for Energy and Leader of the Houses of Commons and Lords. ${ }^{197}$ As members of these various communities, directors have strong incentives to perform their duties in a manner that does not damage their reputation within these communities. ${ }^{198}$ Then too, some board members hold multiple directorships. ${ }^{199}$ Indeed, most of Enron's board members served as directors on other corporation's boards. ${ }^{200}$ Because directors' conduct on one board could have repercussions for their service on other boards, directors have an interest in ensuring that their specific reputation as a director remains unblemished. Directors' desire to protect their specific and general reputation should compel them to behave appropriately: Directors' failure to adequately meet their responsibilities may undermine their reputation, not only causing them to lose their seat as a board member, but also damaging their reputation in the larger community. ${ }^{201}$ In this way, the threat of reputational sanctions should be an ideal method of ensuring that directors fulfill their fiduciary obligations, thereby making legal sanctions unnecessary.

Another argument used to reject the need for legal sanctions focuses on the regulating force of the capital market. Scholars maintain that the capital market effectively regulates corporate conduct by deterring directors from taking actions (or failing to take actions) that adversely affect their corporations' stock price. ${ }^{202}$ Under this theory, when corporate officers and directors

196. See 2001 Proxy Statement of Enron Corp. at 5 (as filed with the SEC on March 27, 2001) [hereinafter Enron Proxy Statement] (listing biographical information on Enron director Robert K. Jaedicke), available at http://budurtha.georgetown.edu/enron/Proxy2001_March_27.htm.

197. See id. at 4-7.

198. See, e.g., Jayne W. Barnard, Reintegrative Shaming in Corporate Sentencing, 72 S. CAL. L. REV. 959, 966-68 (1999) (noting the significance of reputation for corporate officers and directors).

199. See Lisa DiCarlo, Corporate Governance: America's Most Overworked Directors, FORBES.COM, Aug. 6, 2002, at http://www.forbes.com/2002/08/06/0806directors.html (showing that although most outside directors serve on only one board, 807 directors of S\&P 500 companies serve on two or more boards).

200. See Enron Proxy Statement, supra note 196, at 2-5.

201. See supra notes 193, 195 (describing the impact of reputational sanctions on directors)

202. See Daniel R. Fischel, The Corporate Governance Movement, 35 VAND. L. REV. 1259, 1263-64 (1982) (explaining the regulatory impact of markets, direct monitoring, and legal rules on management interests); Sean J. Griffith, Deal Protection Provisions in 
fail to behave responsibly, thereby engaging in conduct that harms shareholders and their profits, the harm is reflected in lowered stock prices. ${ }^{203}$ The more harmful the conduct, the more devastating the impact it will have on a corporation's bottom line. ${ }^{204}$ These lowered stock prices negatively impact a corporation in a multitude of ways. ${ }^{205}$ Indeed, low stock prices not only serve to repel potential investors, but also can lead existing shareholders to sell their interests in the corporation. Moreover, poor stock prices may decrease a corporation's credit rating, making it more difficult or costly to secure credit financing. ${ }^{206}$ Then too, low stock prices make it difficult for corporations to raise capital by hosting a public offering. ${ }^{207}$ Low stock prices also may make a corporation vulnerable to takeover attempts, potentially jeopardizing the positions of officers and directors. ${ }^{208}$ Directors who seek to avoid lowered stock prices and their negative consequences will not engage in the harmful conduct that can trigger a decline in stock prices. Theoretically, the market's ability to regulate director conduct in this manner negates the need for legal sanctions.

Unfortunately, neither the market nor the threat of reputational damages fulfilled their regulatory function for Enron or WorldCom directors, discrediting the notion that the existence of such measures obviates the need for legal sanctions. Certainly, the repercussions these directors faced appear to

the Last Period of Play, 71 Fordham L. REv. 1899, 1937 (2003) (noting that corporate officers and directors are constrained by various markets); Paredes, supra note 19, at 523 (noting the markets' impact on corporate governance); Phillips, supra note 193, at 673-83 (emphasizing the impact of markets on corporate behavior). Other markets, including the products and labor markets, also serve to regulate corporate conduct. See Griffith, supra, at 1937 (noting nonjudicial constraints on management that include product, capital, labor, and corporate control markets); Paredes, supra note 19, at 523 (observing that product, capital, management, and corporate control markets serve to regulate conduct); Phillips, supra note 193, at 673 (noting the role of securities, executive employment, and products markets as regulators of managerial behavior). Because it is most relevant, this Article only discusses the impact of the securities market on corporate conduct.

203. Phillips, supra note 193, at 673.

204. See id. at 673-75 (hypothesizing that "[b]oth equity and debt securities prices should suffer," making it difficult for "the corporation to repay its debt").

205. Id. at 674-75.

206. Griffith, supra note 202, at 1937-38 (emphasizing that misbehavior will decrease access to capital markets and make firms unable to raise debt financing at competitive rates).

207. See id. at 1937-38 (commenting that a firm's misbehavior makes raising equity difficult).

208. See Phillips, supra note 193, at 678-80 (suggesting that low stock prices increase the likelihood that a corporation will be targeted for a takeover); Ribstein, supra note 34 , at 7-8 (positing that the market develops mechanisms such as hostile takeovers to eliminate managers that perform poorly). 
represent an eloquent demonstration of the damaging impact directors' misconduct can have on their reputations, seeming to validate the importance of reputational sanctions. Indeed, all of the Enron board members present during the company's collapse felt the need to resign their positions at Enron. ${ }^{209}$ Moreover, several institutional shareholders and watchdog groups have begun pressuring other public companies with Enron board members not to renominate or reelect ex-Enron directors. ${ }^{210}$ In the wake of this kind of pressure, many Enron directors have voluntarily resigned from their board positions at other companies. ${ }^{211}$ Some investor groups also have asked the SEC to impose lifetime bans on these directors, indicating that the damage to their reputations as directors may be irreparable. ${ }^{212}$ As one Columbia University professor explained, "Anyone who sat on Enron's board as the company unraveled could find themselves persona non grata." ${ }^{213}$ In this respect, Enron reveals the damage that can occur to a director's position and status in the community when she is perceived to have behaved irresponsibly. Unfortunately, the Enron directors' apparent acquiescence in corporate misconduct reveals that the possibility of such damage was not enough to compel directors to perform

209. See Carrie Johnson, After Enron, a New Focus on Boards: Case Spawns a Number of Reform Proposals, WASH. Post, Mar. 8, 2002, at E1 [hereinafter Johnson, After Enron] (noting that as of March 8, 2002, only half of Enron's board members remained); Johnson, supra note 30 (reporting that, as of July 7, 2002, all Enron board members had resigned).

210. See Johnson, After Enron, supra note 209 (noting the AFL-CIO's "campaign to prevent Enron directors from serving on other boards"); Matt Krantz \& Noelle Knox, Some Enron Board Members Leave Other Firm's Rosters, USA TODAY, Feb. 11, 2002, at 1B (referring to the New York City Pension Funds and Retirement System's plan to persuade six companies not to renominate Enron board members); Louis Lavelle, Enron Directors: Unfit to Serve Anywhere?, Bus. WK. ONLINE, Feb. 12, 2002, at http://www. businessweek.com/bwdaily/dnflash/feb2002/nf20020212_1828.htm (pointing out that the "AFL-CIO has called on the 20 public companies where... Enron directors still hold board seats ... not to nominate those directors for new terms," while another watchdog group pushed for directors to resign from posts on the governing boards of Harvard University and Qualcomm).

211. See Krantz \& Knox, supra note 210 (reporting the voluntary resignations of several Enron board members from other board rooms); Lavelle, supra note 210 (noting, among others, the voluntary resignation of Kenneth Lay, former chairman of Enron's board, from his position at Enron as well as three other positions that he held, and the resignation of Enron's chair of the audit committee from his board positions); Dan O'Shea, Ex-Enron Director Leaves Qualcomm Post, Insight, May 18, 2004, 2004 WL 79648524 (reporting the resignation of Enron director Frank Savage from Qualcomm despite his reelection and implying that the resignation may have resulted from pressure by outside groups).

212. See Lavelle, supra note 210 (noting the AFL-CIO request, as well as more than forty individual shareholder requests, for such bans).

213. See Krantz \& Knox, supra note 210 (quoting Professor Robert Bontempo). 
their responsibilities in a more diligent manner. Hence, reputation-based sanctions appeared to have failed in their primary goal of curbing the director misbehavior that contributed to Enron and other instances of corporate malfeasance. ${ }^{214}$

Similarly, Enron appears to be an example of market failure. ${ }^{215}$ Indeed, market-based regulation depends on harmful conduct being reflected in lowered stock prices, and in the case of Enron, this reflection did not occur. ${ }^{216}$ Instead, despite the fact that Enron managers engaged in conduct detrimental to shareholders and the corporation, market watchers continued to issue buy orders for Enron stock almost right up until the corporation declared bankruptcy. ${ }^{217}$ In this way, the market failed to reflect the harmful conduct of its directors and managers until it was too late. From this perspective, because the market failed to provide signals of corporate misconduct through lowered stock prices, it failed as a means of regulating that conduct. ${ }^{218}$

The inability of market and reputational forces to ensure appropriate board behavior suggests the necessity of legal sanctions. As Part II revealed, the legal regime under which the directors in Enron operated carried little if any threat of legal liability for directors' failure to perform their fiduciary obligations. $^{219}$ In that sense, the regime relied completely on extra-legal sanctions to regulate director behavior. This reliance proved inadvisable, highlighting the potential necessity of legal sanctions as a component of the corporate governance system.

\section{B. Reexamining the Utility of Legal Sanctions}

While scholars acknowledge that Enron demonstrated the failure of extra-legal measures, they express doubt about the

214. This Article does not deny the fact that reputational sanctions may represent an appropriate method of punishing directors and that such sanctions may serve as a future deterrent for other directors. However, it does assert that these sanctions did not serve to deter the specific misconduct at issue in Enron and many other corporations involved in corporate malfeasance.

215. See Ribstein, supra note 34, at 53 (arguing that "[c]orporate frauds ... were facilitated because there was too much investor confidence").

216. See id.; Jonathan R. Macey, Efficient Capital Markets, Corporate Disclosure, and Enron, 89 CORNELL L. REV. 394, 417-18 (2004) (observing that "[s]ecurities markets function efficiently when share price fully reflects information about the issuer" but that "Enron's collapse casts some serious doubts on the efficiency of the market").

217. See Macey, supra note 216, at 403-04; David Millon, Who "Caused" the Enron Debacle, 60 WASH. \& LEE L. REV. 309, 321-23 (2003).

218. See Ribstein, supra note 34 , at 53-54 (commenting on the market signals failure).

219. See supra Part II. 
ability of legal measures to curb director irresponsibility. ${ }^{220}$ On the one hand, these critics argue that the nature of director behavior makes it difficult to deter this irresponsible behavior through legal sanctions. ${ }^{221}$ On the other hand, the critics argue that evidence of legal sanctions' ability to deter illegal behavior is relatively weak and thus legal sanctions cannot be relied on to shape director behavior. ${ }^{222}$ This subpart reveals the flaws in both of these arguments.

Economic theory, particularly the rational choice theory, suggests that significant legal penalties in the form of financial sanctions or incarceration are a powerful source of deterrence because they make the costs of illegal behavior outweigh the benefits. $^{223}$ Because the theory works best when applied to individuals who can assess rationally the costs and benefits of their actions, many scholars presume that the theory has particular applicability to those who might engage in "white collar" ${ }^{224}$ crime, including directors who engage in planning, deliberation, and risk assessment. ${ }^{225}$ The economic theory also

220. See Moohr, supra note 180, at 968, 973-74 (suggesting a "wholesale failure of every monitor," but deemphasizing the role of criminal penalties); Paredes, supra note 19, at 523-26 (expressing a preference for a market-based response); Ribstein, supra note 34, at 47-48 (noting a preference for market-based regulations despite its flaws and pointing out that "it was markets and not regulators that uncovered the problems").

221. See, e.g., Moohr, supra note 180, at 961 ("Unless individuals recognize that proposed conduct triggers criminal sanctions, they will not pause to evaluate the risk of detection and punishment.").

222. See, e.g., John Braithwaite \& Toni Makkai, Testing an Expected Utility Model of Corporate Deterrence, 25 LAW \& Soc'Y REV. 7, 29-35 (1991) (concluding from study results that "there is little warrant for accepting the deterrence hypotheses"). In a study of 410 managers of Australian nursing homes, the authors found that most sanction threats did not have the expected deterrent effect. See id. at 17, 31 ("When considering [serious] deterrent threats... once the expected disutility of punishment passes a certain threshold, further increases make little difference.").

223. See, e.g., Kenneth G. Dau-Schmidt, An Economic Analysis of the Criminal Law as Preference-Shaping Policy, 1990 DukE L.J. 1, 5, 10-11 (explaining that a person will "decide to engage in the activity only if the benefits she receives exceed the external costs"); accord Richard A. Posner, An Economic Theory of the Criminal Law, 85 CoLUM. L. REV. 1193, 1195 (1985) (arguing that the "threat of punishing attempts [at crime] ... makes the completed crime more costly in an expected sense and therefore less likely to be committed").

224. The term "white collar crime" was coined by Edwin H. Sutherland, who defined it as a crime "committed by a person of respectability and high social status in the course of his occupation.” EDWIN H. SUTHERLAND, WHITE COLLAR CRIME 9 (1949).

225. See, e.g., Darryl K. Brown, Street Crime, Corporate Crime, and the Contingency of Criminal Liability, 149 U. PA. L. REV. 1295, 1325 (2001) (noting the applicability of deterrence theory to corporate crime); Sanford H. Kadish, Some Observations on the Use of Criminal Sanctions in Enforcing Economic Regulations, 30 U. CHI. L. REV. 423, 425-26, 443 (1963) (suggesting that corporate criminals whose crimes are "calculated and deliberate" are easily deterred by the possibility of corporate stigma); Moohr, supra note 180, at 957-58 (explaining that the rational choice theory resonates in the area of 
has particular relevance for individuals because they are not committed to a life of crime and consequently will abandon improper behavior if the costs of that behavior prove too high. ${ }^{226}$ Thus, economic theory suggests that legal sanctions may be exactly what the corporate governance system needs in order to ensure that directors carry out their responsibilities faithfully.

1. Legal Sanctions and the Nature of Director Misconduct. Some scholars question the applicability of the economic theory, and specifically the rational choice theory, to director conduct. The rational choice theory presupposes that actors can distinguish between legal and illegal behavior and make a choice about the behavior in which they will engage based on that distinction. ${ }^{227}$ However, if the law does not clearly define the kind of conduct considered illegal, then the rational choice theory can no longer be applied because a "choice" regarding whether or not to engage in illegal conduct cannot be made. ${ }^{228}$ This effect may be the case with regard to directors. Indeed, scholars note that our corporate regime does not accurately define the kind of director conduct considered to be a violation of a director's duty. ${ }^{229}$ Instead, the parameters of these violations are vague and "famously written in shades of gray." Even though directors should understand that, based on existing case law, failing to pay sufficient attention to corporate actions or to ask the appropriate number of questions regarding corporate transactions represents a breach of their fiduciary responsibilities, ${ }^{231}$ this general understanding falls short of pinpointing the specific conduct that

business crime because these crimes require advance planning, which allows one to assess the risk of detection and punishment).

226. See William J. Chambliss, Types of Deviance and the Effectiveness of Legal Sanctions, 1967 WIS. L. REV. 703, 709-10 (concluding that "[w] here penal sanctions are imposed there is a decline in the propensity to violate the law"); Kadish, supra note 225, at 434 (" $[\mathrm{T}]$ he corporate stigma may operate as a deterrent by impairing the reputation of the corporation... and hence adversely affecting its economic position."); see also John Braithwaite \& Gilbert Geis, On Theory and Action for Corporate Crime Control, 28 CRIME \& DELINQ. 292, 300-02 (1982) (positing that white collar offenders are more easily deterred because they are not committed to a life of crime).

227. See Raymond Paternoster \& Sally Simpson, Sanction Threats and Appeals to Morality: Testing a Rational Choice Model of Corporate Crime, 30 LAW \& Soc'Y REv. 549, 550-56 (1996) (explaining assumptions upon which the rational choice model is based).

228. See Moohr, supra note 180, at 960 (arguing that "if individuals do not realize that their conduct is criminal or even borders on it, they will not engage in a rational calculation").

229. See id. at 960-61 ("[S]uch laws fail to provide notice that certain conduct is criminal.").

230. Id. at 959 .

231. See supra notes 15-18 (discussing cases detailing breaches of fiduciary duty). 
triggers such a breach. ${ }^{232}$ For example, will a director be liable for breaching her duty of attention by failing to attend one board meeting? What if the director attends every board meeting, but asks no questions? If the director does ask questions, how many questions will be sufficient to satisfy her fiduciary obligations? That case law provides no definite answers to these questions makes it difficult for directors to assess the appropriateness of their conduct, and thus poses a problem for any deterrence theory of liability based on the rational choice model. From this perspective, the rational choice theory is ill-suited as a justification for imposing legal sanctions on directors.

This perspective, however, overemphasizes directors' inability to distinguish between legal and illegal conduct. In fact, some cases do provide greater substance and specificity with respect to the kinds of behavior that violate a director's fiduciary responsibility. ${ }^{233}$ At least one case explains that the failure to review any financial statements or to have a rudimentary understanding of corporate affairs subjects one to liability. ${ }^{234}$ Similarly, approving a merger without reviewing and understanding the specific financial information on which the merger price was based will subject directors to liability. ${ }^{235}$

Then too, many self-regulating agencies have issued corporate governance principles aimed at creating greater specificity regarding the proper conduct for corporate actors. ${ }^{236}$ Most notably, the Business Roundtable, an association of CEOs from top corporations, has published Principles of Corporate Governance, a publication detailing the elements of acceptable board behavior. $^{237}$ The Business Roundtable requires directors to have an attitude of "constructive skepticism" pursuant to which they must both understand the substance of all reports and "ask questions and obtain answers" about the process used by managers to reach

\footnotetext{
232. See Moohr, supra note 180, at 960 (highlighting the point that laws are "written in nonspecific, general terms").

233. See, e.g., Smith v. Van Gorkom, 488 A.2d 858, 864 (Del. 1985) (holding directors responsible for uninformed business judgments, ineffectual curative actions, and lack of candor with stockholders); Francis v. United Jersey Bank, 432 A.2d 814, 822 (N.J. 1981) (defining with specificity conduct required of directors such as regular attendance at board meetings).

234. See Francis, 432 A.2d at 821-22.

235. See Van Gorkom, 488 A.2d at 881.

236. See generally Business Roundtable, supra note 12 (outlining a complete corporate governance system)

237. See id. at 10-29.
} 
important decisions. ${ }^{238}$ With regard to financial matters, the Business Roundtable states the following:

[T] he board, through its audit committee, should have a broad understanding of the corporation's financial statements, including why the accounting principles critical to the corporation's business were chosen, what key judgments and estimates were made by management, and how the choice of principles, and the making of such judgments and estimates, impacts the reported financial results of the corporation. ${ }^{239}$

The existence of these kinds of statements undermines the notion that directors lack guidance regarding the appropriate boundaries of their behavior. In addition, the vast majority of corporations have adopted codes of conduct or ethics, outlining the kinds of behavior that satisfy a director's fiduciary duty. ${ }^{240}$ These codes include provisions regarding the manner in which directors should review and oversee corporate affairs and financial operations. ${ }^{241}$ Indeed, investigations reveal that Enron had adopted such a code and that Enron directors violated it repeatedly. ${ }^{242}$ And even if these codes are unclear, SarbanesOxley's provision involving directors adds even greater specificity to directors' duties. ${ }^{243}$

These varied statements addressing director conduct undermine the suggestion that corporations and other entities fail to provide sufficient detail regarding the manner in which

\author{
238. Id. at $3-4$. \\ 239. Id. at 5 . \\ 240. See, e.g., Center for Business Ethics, Are Corporations Institutionalizing
} Ethics?, 5 J. BUS. ЕтнICS 85, 85-86 (1986) (stating that almost eighty percent of the 279 Fortune 500 companies reviewed reported taking at least preliminary steps to "incorporate ethical values ... into [their organizations'] daily operations"); Harvey L. Pitt \& Karl A. Groskaufmanis, Minimizing Corporate Civil and Criminal Liability: A Second Look at Corporate Codes of Conduct, 78 GEO. L.J. 1559, 1602 n.257 (1990) (noting that $94.7 \%$ of companies surveyed in a 1987 Georgetown study had adopted codes of conduct); Bernard J. White \& B. Ruth Montgomery, Corporate Codes of Conduct, 23 CAL. MGMT. REV. 80, 82 (1980) (reporting that seventy-seven percent of companies had codes of conduct in 1979); Carolyn Wiley, The ABC's of Business Ethics: Definitions, Philosophies and Implementation, INDUS. MGMT., Jan.-Feb. 1995, at 22, 24 (reporting that ninety percent of Fortune 500 companies and about half of other companies have adopted codes of conduct).

241. See White \& Montgomery, supra note 240, at 84-85 (detailing the subjects addressed by the codes sampled).

242. See Powers Report, supra note 22, at 28, 46-47, 77 (noting the board's failure to comply with Enron's Code of Conduct); see also O'Connor, supra note 20, at 1236-37 (commenting that Enron "followed many of the best practices for good corporate governance").

243. See Sarbanes-Oxley Act § 906, 18 U.S.C. $§ 1350$ (2002) (outlining, for example, duties regarding financial reports). 
directors should comply with their responsibilities. ${ }^{244}$ Rather, they suggest that directors understand their responsibilities but choose to ignore them, which certainly appears to be the case with Enron directors. Directors' decisions to ignore their obligations not only reveal that they can make a choice about their conduct (thus validating the application of the rational choice theory to their conduct), but also that an additional mechanism may be needed to ensure that the choice directors make is the correct one.

2. Legal Sanctions and Their Deterrent Value. Of course, some scholars argue that legal liability cannot be that mechanism. These scholars question the ability of legal sanctions to deter illegal behavior generally and director misconduct specifically. Admittedly, there is some empirical data suggesting that legal sanctions have very little deterrent value. ${ }^{245}$ More specifically, the existence of a large body of legal sanctions during the Enron debacle suggests their failure to impact director behavior. Indeed, there are allegations that some Enron directors may have violated several laws in existence prior to SarbanesOxley. ${ }^{246}$ The penalties for these violations would have been quite severe. For example, an individual found liable for securities fraud could have been subjected to a one million dollar fine or a maximum prison term of ten years. ${ }^{247}$ Directors' willingness to engage in inappropriate behavior despite these penalties raises doubts about the ability of legal sanctions to deter corporate misbehavior. Despite these doubts, the thrust of SarbanesOxley's legal sanctions centers on enhancing legal penalties. ${ }^{248}$

244. See Pitt \& Groskaufmanis, supra note 240, at 1602-03 \& n.261 (discussing subjects commonly detailed in corporate codes).

245. See Braithwaite \& Makkai, supra note 222, at 29 (concluding that criminal sanctions failed to deter the conduct of nursing home managers in Australia); Sally S. Simpson \& Christopher S. Koper, Deterring Corporate Crime, 30 CRIMINOLOGY 347, 34748 (1992) (finding little support for the deterrence theory among antitrust violators).

246. For example, Enron's Chairman of the Board, Kenneth Lay, was recently charged with securities fraud and insider trading. John R. Emshwiller et. al, Lay Strikes Back as Indictment Cites Narrow Role in Enron Fraud, WALL ST. J., July 9, 2004, at A1. Both Jeffrey Skilling, former Enron CEO, and Bernard Ebbers, former WorldCom CEO, were charged with securities fraud. Jeffrey H. Birnbaum, Targeting the Top in Corporate Crime: Prosecutors Are Working to Hold Former Executives Accountable, WASH. PosT, Mar. 3, 2004, at A8.

247. See supra text accompanying note 179 (describing previous penalties for securities fraud).

248. Indeed, Sarbanes-Oxley includes an entire section entitled "White-Collar Crime Penalty Enhancements" that augments the criminal penalties for various federal securities law violations. Sarbanes-Oxley Title IX (codified as the White-Collar Crime Penalty Enhancement Act, 18 U.S.C. $\S 1341,1343,1349$, 1350, 28 U.S.C. § 94, 29 U.S.C. $\S 1131(2002))$. 
For example, the Act increases the maximum penalty for securities fraud from ten years in prison or one million dollars in fines or both, to twenty years in prison or five million dollars in fines or both. ${ }^{249}$ However, critics condemn these increases, pointing out the lack of evidence that the increased penalties will do any more to deter directors' behavior than the penalties in existence prior to Sarbanes-Oxley. ${ }^{250}$

This condemnation may be misguided because it discounts the studies emphasizing the importance of enhancement while failing to give sufficient weight to the importance of certainty in improving the deterrent value of legal liability. Although some empirical and anecdotal evidence supports the notion that merely enhancing legal penalties does little to deter wrongdoing, other studies contradict this evidence. ${ }^{251}$ These studies confirm the importance of enhanced penalties in deterring illegal behavior while criticizing the limited scope of studies that reach an opposite result. ${ }^{252}$ Moreover, such studies demonstrate that

249. See Sarbanes-Oxley Act $\S 1106$ (amending 15 U.S.C. $§ 78 f f$ ). Sarbanes-Oxley also increases the maximum penalty for mail and wire fraud from five years to twenty years in prison. See Sarbanes-Oxley Act $§ 903$ (amending 18 U.S.C. $\S ~ 1341,1343$ ).

250. See Moohr, supra note 180, at 955 (questioning the effectiveness of imposing more severe penalties as a means to increasingly deter corporate misconduct); Ribstein, supra note 34, at 34 (noting that recent incidents of fraud suggest that corporate officials are willing to risk liability and reputational damage, and hence it is unlikely that added liability will produce additional constraints on behavior). It is notable that many of the scholars who question the power of legal sanctions argue that imposing these sanctions on directors may prove too powerful by causing some directors to be overly cautious and others to refuse to serve at all. It seems contradictory to claim that sanctions are too weak to deter illegal conduct, yet powerful enough to threaten the corporation's ability to appoint directors willing to make appropriate business decisions. It may be true that for people who are already predisposed to commit fraud, the threat of personal liability may neither prevent them from seeking a directorship nor deter them from engaging in inappropriate conduct once they secure that position. However, for otherwise honest and law-abiding people, one would expect that the legitimate threat of legal sanctions not only would cause them to think twice before accepting a directorship, but also think twice (and ask twice the questions) before acquiescing in the disclosure of questionable or inaccurate information about their corporation. Although this debate reveals that these sanctions may be a double-edged sword, it also supports the notion that they can serve as one of the most powerful regulators of corporate conduct.

251. See Richard C. Hollinger \& John P. Clark, Deterrence in the Workplace: Perceived Certainty, Perceived Severity, and Employee Theft, 62 Soc. FoRCES 398, 407-08, 413-14 (1983) (finding that increased certainty and severity of negative consequences deterred employee theft); Mary Kreiner Ramirez, Just in Crime: Guiding Economic Crime Reform After the Sarbanes-Oxley Act of 2002, 34 LoY. U. CHI. L.J. 359, 414-17 (2003) (recognizing the difficulties surrounding empirical testing of the effects of penalties on the rate of white-collar crime but concluding that the imposition of stiff prison sentences is necessary to discourage economic crime); Simpson \& Koper, supra note 245, at 360 (finding that sanction severity deterred some offenders).

252. See Paternoster \& Simpson, supra note 227, at 552-53 (noting the failure of previous studies to consider the combined deterrence effects of formal and informal sanctions against white-collar crime). 
increasing the certainty of legal sanctions effectively deters misconduct. ${ }^{253}$ Thus, a study of MBA students and corporate executives found that legal sanctions had a significant deterrent effect on the decision to engage in illegal corporate acts. ${ }^{254}$ Like other studies, this study revealed that in order for legal sanctions to deter misconduct, there must be certainty-a legitimate risk that such sanctions will be imposed. ${ }^{255}$ Part II.B revealed that prior to Sarbanes-Oxley, such a risk was not present. This view is consistent with empirical research highlighting the fact that white-collar criminals rarely face prosecution or significant legal penalties for their crimes. ${ }^{256}$ This research suggests that legal sanctions fail to constrain director misbehavior because of the relatively low risk that such sanctions will actually be imposed. Thus, to the extent that critics rely on the failure of legal sanctions to curb director misconduct as evidence of the ineffectiveness of legal liability as a whole, ${ }^{257}$ their criticism is misguided. Instead, most evidence supports the notion that legal sanctions can serve as a powerful deterrent to misconduct when properly implemented. ${ }^{258}$

253. See Hollinger \& Clark, supra note 251, at 399 ("[O]f the three major variables in the deterrence process-perceived certainty, severity, and celerity of punishment-the consensus of empirical research is that perceived certainty of punishment is the most effective in shaping behavior."); Steven Klepper \& Daniel Nagin, Tax Compliance and Perceptions of the Risks of Detection and Criminal Prosecution, 23 LAW \& Soc'y REv. 209, 210-11, 237-39 (1989) (finding that a greater risk of detection and prosecution deterred people from cheating on their taxes); see also Simpson \& Koper, supra note 245, at 348 ("Empirical studies... suggest... that certainty of sanction is more important than severity.").

254. See Paternoster \& Simpson, supra note 227, at 557, 579-80 (concluding that threats of criminal and civil sanctions serve as an effective deterrent to corporate crime).

255. See id. at 578-79 (noting that sanctioning businesses as well as individuals significantly discourages employees from engaging in wrongdoing); see also Fairfax, supra note 21 , at $50-51$ (explaining experts' belief that criminal penalties deter crime when criminals face certainty of punishment).

256. See Joseph E. Kennedy, Making the Crime Fit the Punishment, 51 EmoRY L. J. 753,756 (2002) (finding that the Federal Sentencing Guidelines promulgated in the 1980s had the perverse effect of encouraging judges to become more lenient by interpreting criminal statutes in a light more favorable to the accused); Ramirez, supra note 251, at 397-98 (showing that judges often sentenced white-collar criminals at the lowest end of permitted range under the Federal Sentencing Guidelines or permitted downward departures from the prescribed minimums); see also Fairfax, supra note 21, at 57-59 (reviewing evidence revealing that white collar criminals have a low probability of being prosecuted and receive relatively light penalties).

257. See Moohr, supra note 180, at 943 (noting that increased sentencing minimums for certain white-collar offenses failed to reduce crime).

258. See supra notes 251-55 and accompanying text (pointing to studies that show a correlation between the increased certainty and severity of punishment and deterrence of crime). 
This analysis reveals that Sarbanes-Oxley's new sanctions could be effective if there were a legitimate certainty that such sanctions would be imposed. Part II.C demonstrated ways in which the Act may increase directors' exposure to liability under state law and revealed that the Act may increase the ability to prove directors' knowledge of corporate misdeeds, thereby increasing the ability to hold directors liable for federal securities law violations. If the Act has such an impact, then it may lead to a greater probability that directors will be held legally accountable for their misbehavior. If this renewed certainty occurs, then Sarbanes-Oxley could increase the deterrent impact of legal sanctions.

However, Part II.C also demonstrated that SarbanesOxley may not significantly enhance the possibility that directors will face legal liability for violations of their duty. ${ }^{259}$ In this regard, Sarbanes-Oxley may be flawed. By failing to impose direct legal liability on directors for their misconduct, ${ }^{260}$ the Act may fail to enhance certainty and thus may undermine the deterrent effect of legal penalties both specifically within the Act and more generally. Thus, Sarbanes-Oxley may represent a missed opportunity to infuse greater certainty, and hence the necessary deterrent, into legal liability.

Of course, any increased certainty depends upon a heretofore-lacking willingness to impose significant legal penalties on corporate directors. ${ }^{261}$ Evidence suggests not only a relatively low risk that directors will be prosecuted, and thus convicted, for their crimes, but also that directors tend to receive light, if any, penalties after being convicted. $^{262}$ Although there are various reasons for this phenomenon, our legal system appears to lack the will to hold directors personally liable for dereliction of their duties. ${ }^{263}$ This

259. See supra notes 184-87 (discussing the possibility that corporate insurance and state incorporation laws may continue to shield directors from liability).

260. See supra text accompanying notes 188-89 (expressing concern that SarbanesOxley may have deferred to state law with respect to remedies for directors' violations of fiduciary duty).

261. See, e.g., G. Robert Blakey \& Scott D. Cessar, Equitable Relief Under Civil RICO: Reflections on Religious Technology Center v. Wollersheim: Will Civil RICO Be Effective Only Against White-Collar Crime?, 62 NotRE DAME L. REv. 526, 568 n.191 (1987) (explaining why the government has shown lenience toward economic crime).

262. See Fairfax, supra note 21, at 57-58 (describing studies on white collar criminals showing low prosecutions and minimal punishment).

263. See id. at 59-60 (listing society's reluctance to treat economic crimes harshly, the view that white-collar defendants are sufficiently penalized by criminal adjudication, and the (typically) superior economic status of white-collar defendants as explanations for "the tendency to treat white-collar criminals with kid gloves"). In fact, experts advance various 
weakness in our legal system represents one reason why directors have faced a low risk or certainty of punishment. ${ }^{264}$ However, the arrest, prosecution, and even conviction of highprofile corporate officers from Martha Stewart ${ }^{265}$ to former

reasons why white-collar criminals may be considered less culpable than other criminals. See, e.g., Stanton Wheeler et Al., Sitting In Judgment: The Sentencing Of White CollaR CRIMINALS 192 (1988) (noting that judges tend to be more lenient toward white-collar offenders who may "remind [them] of a colleague or neighbor, while the street offender is no more than a stranger"); Brown, supra note 225, at 1331-32 (attributing the availability of civil penalties for white-collar crime - unlike street crime - and the nature of its social costs as explanations for the imposition of civil, rather than criminal, liability). Some argue that because white-collar offenses do not involve violence, those who commit such offenses are less deserving of harsh legal sanctions than those who commit violent offenses. See WHEELER ET AL., supra, at 144-46 (discussing the belief of some judges that the criminal prosecution of white-collar criminals "is itself a kind of punishment" because of the defendants' loss of reputation and public humiliation, while street-criminals holding "low social status" do not suffer the same loss); see also J. Kelly Strader, The Judicial Politics of White-Collar Crime, 50 HASTINGS L.J. 1199, 1264-65 (1999) (interpreting Justice White's dissent in Harmelin v. Michigan, 501 U.S. 957, 1023 (1991) (White, J., dissenting), as suggesting that 'the defendant's 'moral guilt' was less than that of violent criminals"). Others argue that because many people who commit whitecollar offenses do not have a history of criminal or illegal behavior, they are less culpable than other offenders. See WHEELER ET AL., supra, at 88-90 (illustrating how judges show more lenience toward first-time offenders and noting that most white-collar defendants have no prior record). Some may suggest, in fact, that directors are less culpable than their executive counterparts and hence less deserving of legal sanctions because a director's role is passive and involves a failure to monitor, as opposed to active engagement in the fraudulent actions. See, e.g., Graham v. Allis-Chalmers Mfg. Co., 188 A.2d 125, 130-31 (Del. 1963) (refusing to impose an affirmative duty upon directors to police wrongdoing within the corporation). This characterization suggests that it is inappropriate to hold directors legally liable for their actions (or inactions), especially if such liability takes the form of incarceration. Such a rationale may explain the differential treatment between directors and their managerial counterparts, the latter of whom are deemed to be more involved in the daily affairs of the corporation and hence more culpable. See supra notes 72-76 (contrasting the penalties imposed on directors and officers). This issue about the relative culpability of directors deserves greater attention and is beyond the scope of this Article. However, it should be noted that both the Guidelines and Sarbanes-Oxley appear to recognize that those who commit economic crimes have greater culpability than is traditionally believed. See Moohr, supra note 180, at 941-43, 954-55 (describing the Federal Sentencing Guidelines as mandating strict penalties for economic crimes even before Sarbanes-Oxley and stating that Sarbanes-Oxley has further increased maximum prison sentences for certain white-collar crimes by several hundred percent). Then too, arguments downplaying directors' culpability minimize the significant monitoring role directors must undertake when carrying out their fiduciary responsibilities. See In re Caremark Int'l Inc., 698 A.2d 959, 968-70 (Del. Ch. 1996) (recognizing the important role directors play in ensuring the well-being of the business and requiring them to establish sufficient monitoring systems within the corporation).

264. Dan M. Kahan, Social Influence, Social Meaning, and Deterrence, 83 VA. L. REv. 349 , 378-79 (1997) (arguing that lack of certainty will lead "some potential law-breakers [to] infer that crime pays," which will encourage them to "act accordingly").

265. See Brooke A. Masters, Martha Stewart Sentenced to Prison: Punishment Postponed as She Appeals Verdict, WASH. PoST, July 17, 2004, at A01 (reporting that Stewart received a sentence of five months in prison and five months in home confinement); Brooke A. Masters \& Ben White, Stewart Guilty on All Charges: Businesswoman Conspired with Broker, Jury Says, WASH. POST, Mar. 6, 2004, at A01 (announcing Stewart's conviction for conspiracy, obstruction, and lying to federal investigators). For a discussion of the Martha Stewart case, see generally Joan MacLeod Heminway, Save Martha Stewart? Observations About Equal Justice in U.S. 
Enron CFO Andrew Fastow ${ }^{266}$ suggest a rejection of this weakness. ${ }^{267}$ Not only did judges in these cases appear less lenient than usual, but some legal experts remarked that the severity of the sentences were unprecedented in the context of white-collar crime. $^{268}$ More significantly, that Enron and WorldCom directors agreed to bear millions of dollars in personal liability as part of settlement agreements with shareholderseven though judges had dismissed suits for securities fraud against them-suggests shareholders' determination to hold directors personally liable. ${ }^{269}$ These events increase the certainty of legal liability, even if only temporarily. ${ }^{270}$ Moreover, because of their high-profile nature, these new penalties send a signal to corporate officials that may alter their perception of their potential criminal liability and that should reverberate for years to come. ${ }^{271}$ In this regard, these events may increase certainty of punishment, which in turn should increase the deterrent impact of legal remedies.

This assessment refutes concerns that legal sanctions cannot be useful deterrents. If there are sufficient signals for directors to

Insider Trading Regulation, 12 TEX. J. WoMEN \& L. 247 (2003).

266. See Editorial, Enron Justice, WALL ST. J., Jan. 15, 2004, at A14 [hereinafter Enron Justice] (calling Fastow's sentence "eye-popping," and "among the harshest ever handed down for a white-collar crime"); Carrie Johnson, Lea Fastow Sentenced to 1-Year Term, WASH. POST, May 7, 2004, at E01 [hereinafter Johnson, Lea Fastow Sentenced] (noting that Andrew Fastow received a ten-year prison term after pleading guilty to conspiracy charges and that his wife Lea Fastow was sentenced to a one-year prison term after pleading guilty to filing a false tax return); Carrie Johnson, Enron Wizard Admits Conspiracy, WASH. POST, Jan. 15, 2004, at A01 [hereinafter Johnson, Enron Wizard] (noting that Andrew Fastow pled guilty to two counts of conspiracy and will serve ten years in prison and three years on probation).

267. See Fairfax, supra note 21, at 59-60 (crediting political pressure for the change in attitude toward corporate wrongdoers).

268. For example, the judge overseeing Lea Fastow's plea agreement refused to accept an earlier deal that called for her to spend five months in prison and five months in home confinement. Johnson, Lea Fastow Sentenced, supra note 266. Instead, the judge rejected her plea for leniency and sentenced her to a maximum of one year in prison. Id.; see also Jeffrey H. Birnbaum, Targeting the Top in Corporate Crime: Prosecutors Are Working to Hold Former Executives Accountable, WASH. POST, Mar. 3, 2004, at A08 (quoting Professor John Coffee, who noted that whereas previous cases involving misuse of corporate funds would typically settle, corporate officials now face the possibility of personal liability); Johnson, Enron Wizard, supra note 266 (noting that legal experts called Andrew Fastow's term "unusually stiff" and quoting a Deputy Attorney General who called the sentence "unheard of").

269. See White, supra note 4 (interviewing attorneys for Enron and WorldCom plaintiffs, who noted that the settlements revealed a new phase in which shareholders would push directors to bear much higher personal costs for their fiduciary failures).

270. See Fairfax, supra note 21, at 60-62 (cautioning that changes in attitudes regarding corporate misconduct may be temporary).

271. See Enron Justice, supra note 266, at A14 ("The deterrent effect of seeing Mr. Fastow severely punished is likely to be far more bracing for everyone in business than one more proscription out of Congress or the SEC.”). 
use to distinguish between improper and proper conduct ${ }^{272}$ and if there is some degree of certainty that improper conduct will lead to legal sanctions, then legal sanctions can serve as powerful constraints on directors.

\section{Birds of a Feather . . . : The Interdependence of Legal and Extra-Legal Forces}

In addition to suggesting their relative power, Enron suggests that legal sanctions may be a necessary precondition to the effectiveness of other extra-legal measures. The lesson of Enron may not be simply that legal sanctions are necessary to fill the gap when other measures fail, but rather that these other measures may inevitably fail without the presence of legal sanctions.

1. Deterrence and the Laws of Reputation. Assuming directors do in fact desire to protect their reputation, ${ }^{273}$ one explanation for reputational sanctions' failure to deter director misbehavior may be that directors do not believe their conduct will be detected. Some commentators have noted the difficulties associated with ferreting out corporate crime. ${ }^{274}$ Because of these difficulties, directors of the past may have believed they could commit illegal actions free from detection. ${ }^{275}$ This freedom meant that directors did not have to fear damage to their reputation as a result of such actions. However, this relative difficulty with detecting corporate misconduct actually supports the need for legal penalties. Indeed, several scholars and judges maintain that when people commit acts that involve a low probability of detection, adequate deterrence requires an augmentation of the penalties associated with such acts. ${ }^{276}$ Thus, if the difficulty of

272. See Moohr, supra note 180, at 960 (noting that the potential corporate lawbreaker needs sufficient notice of what constitutes criminal conduct before he can make a rational decision not to engage in unlawful activity).

273. One explanation for the failure of reputational sanctions to deter directors' conduct could be that directors do not care about damage to their reputation. See Edward B. Rock, Saints and Sinners: How Does Delaware Corporate Law Work?, 44 UCLA L. REV. 1009, 1103 (1997) (hypothesizing that businessmen with "sufficiently thick skins" may not be deterred by a mere threat of public shaming). Given their status in the community, however such an explanation appears unrealistic. See CHRISTOPHER CHERNIAK, MINIMAL RATIONALITY 9-11 (1986) (noting that humans are minimally rational beings whose conduct is guided by expected consequences).

274. See Moohr, supra note 180, at 961 (using fraud as an example of an economic crime that is difficult to detect because it "occurs in secret, often by those who are able to control and conceal information that might lead to detection").

275. See id.

276. See, e.g., RICHARD A. Posner, The Economics of Justice, 197 (1981) (“[I]f the probability of punishment is less than one, the fine must be raised so that the expected 
detection explains why directors of the past did not fear reputational sanctions, then the corporate regime must impose significant penalties in order to restore that fear and ensure the effectiveness of reputational sanctions.

This same restoration of fear may also be necessary if reputational sanctions failed because of directors' assessment of their conduct: Another explanation for the ineffectiveness of reputational sanctions may be that the directors-and the communities to which they belonged-did not believe their conduct merited such sanctions. ${ }^{277}$ This belief finds support in the exoneration trend. ${ }^{278}$ In order for the various communities to which directors belong to impose reputational sanctions, such communities must have some standard by which to judge director conduct. ${ }^{279}$ The legal regime plays a critical role in shaping that standard. ${ }^{280}$ The regime defines acceptable conduct

cost of punishment will remain equal to the cost of the violation.”); David A. Dana, Rethinking the Puzzle of Escalating Penalties for Repeat Offenders, 110 YALE L.J. 733, 740 (2001) (noting that optimal deterrence suggests that society should impose greater sanctions against those whose behavior is less likely to be detected); see also, e.g., United States v. Grimes, 173 F.3d 634, 638 (7th Cir. 1999) (noting the need for "a higher than average punishment" for wrongs "less likely to be detected and punished"); United States v. Garrison, 133 F.3d 831, 838 (11th Cir. 1998) (noting that the purpose of a specific sentencing enhancement is to impose increased penalties on those "who take advantage of a position that provides them freedom to commit or conceal a difficult-to-detect wrong"); United States v. Hill, 915 F.2d 502, 504, 506-08 (9th Cir. 1990) (applying a penalty enhancement because the defendant had the "freedom to commit a difficult-to-detect wrong"). In fact, under the Federal Sentencing Guidelines, the ability of a person to commit a crime that is difficult to detect is one of the factors used to establish a "position of public or private trust," the abuse of which merits enhanced sanctions. See U.S. SENTENCING GUIDELINES MANUAL § 3B1.3 (2000) (requiring a two-level increasedculpability adjustment for the abuse of such position).

277. O'Connor, supra note 20, at 1236-40 (explaining how social forces within small groups-like boards of directors-permit the rationalization of forbidden behavior and inhibit the ability of members to engage in objective decisionmaking).

278. See supra notes $265-71$ and accompanying text (discussing the justice system's failure to impose stiff penalties for white-collar crime).

279. See Dan M. Kahan \& Eric A. Posner, Shaming White-Collar Criminals: A Proposal for Reform of the Federal Sentencing Guidelines, 42 J.L. \& ECON. 365, 374-75 (1999) (explaining that government may be instrumental in establishing norms for behavior through shaming penalties, which will eliminate the collective action problems arising from private shaming).

280. See, e.g., Blair \& Stout, supra note 99, at 1797 (explaining the role of judicial opinions in framing social norms); Eisenberg, supra note 108, at 1269-70 (noting that legal rules clarify and facilitate the effectiveness of informal sanctions by sending a message about the proper standard of conduct for directors, which increases the likelihood that reputational penalties will be imposed); Rock, supra note 273, at 1016 (noting that legal rules instruct directors on how to behave and "influence the development of . . social norms"); David A. Skeel, Jr., Shaming in Corporate Law, 149 U. PA. L. REV. 1811,1820 (2001) (noting that norms enforced by shaming cannot survive without enforcement through shaming sanctions-public statements "directed at the offender[s], and addressed to the relevant community"). 
in at least two ways: (1) by providing legal opinions that articulate acceptable behavior, ${ }^{281}$ and (2) by penalizing those who fail to conform to that behavior. ${ }^{282}$ Recently, several scholars have highlighted the important role legal opinions play in defining norms of behavior for directors. ${ }^{283}$ These scholars argue that legal opinions obviate the need for legal sanctions because communities rely on the norms articulated by such opinions to regulate director conduct. ${ }^{284}$ Although compelling, this argument

281. See Rock, supra note 273, at 1016 (characterizing the role of judges as "preachers" whose rulings spur the development of social norms).

282. See Skeel, supra note 280, at 1829 (describing the goal of imposing liability on corporations as a means of controlling corporate behavior).

283. See id. at 1825-26 (noting the key role courts play in shaming corporate criminals); see also Eisenberg, supra note 108, at 1270 (noting that legal cases have an expressive effect and help clarify the standard of conduct for directors); Rock, supra note 273, at 1016-17 (viewing the role of courts as prescribing standards of behavior that constrain corporate actions). Professor Eisenberg defines social norms as "rules and regularities concerning human conduct, other than legal rules and organizational rules." Eisenberg, supra note 108, at 1255 . His scholarly work on social norms as they relate to corporate law builds on a body of literature that examines the importance of social norms in regulating conduct. See generally, e.g., Lisa Bernstein, Opting Out of the Legal System: Extralegal Contractual Relations in the Diamond Industry, 21 J. LEGAL STUD. 115, 116, 138-45 (1992) (discussing the centrality of "reputation bonds" within the diamond industry as a form of "private law"); David Charny, Illusions of a Spontaneous Order: "Norms" in Contractual Relationships, 144 U. PA. L. REV. 1841 (1996) (addressing the broad issues behind the development, function, and economic efficiency of nonlegal norms; whether and when norms should be recognized by law; and analyzing those norms within the American grain industry and the products liability system of Japan); Robert Cooter, Expressive Law and Economics, 27 J. LEGAL STUD. 585 (1998) (using an economic model to explain the influence of social norms on individuals and the internalization and expression of those norms); Cass R. Sunstein, Social Norms and Social Roles, 96 Colum. L. REV. 903 (1996) (examining features and misconceptions of social norms and advocating government participation in the management of social norms). Professor Eisenberg describes three categories of norms, see Eisenberg, supra note 108, at 1256-57, and refers to those that shape director conduct as "obligational norms" with which people feel compelled to comply either because they "internalized the norm[s] or because [they] fear . . . external sanctions" for violating them. $I d$. at 1257-58. Professors Blair and Stout add to this body of work through their discussion of the impact of trust on directors and other corporate agents, noting that judicial opinions frame social norms that encourage corporate actors to view their relationships as cooperative. See Blair \& Stout, supra note 99 , at $1796-98$

284. See Eisenberg, supra note 108, at 1265 (crediting legal authorities with spurring changes in norms regarding the fiduciary obligations of directors); Rock, supra note 273, at 1016-17 (characterizing judicial opinions as "parables" that provide normative guidance to corporate officials but cannot be reduced to rules). Professor Eisenberg notes that a shift in social norms provides one explanation for the divergence between directors' limited exposure to liability and court opinions that stress the importance of the duty of care-these opinions generate the norms to which directors feel obliged to comply. See Eisenberg, supra note 108, at 1268-70. Indeed, these legal rules also impact director conduct even without the input of communities because people internalize the norms created by such rules and these internalized norms in turn shape director behavior. See $i d$. at 1268-69 (describing how the symbiotic relationship between legal rules and social norms explains the changes in attitude toward a director's duty of care). Indeed, Eisenberg notes that while some people adhere to norms based on a fear of reputational 
has at least two flaws. The first flaw is that it fails to appreciate the negative implications the exoneration trend has on the ability of courts to render opinions. Indeed, exculpatory statutes ensure that many cases are dismissed before courts can comment on the merits of the underlying action. ${ }^{285}$ In addition, the combination of D\&O insurance and indemnification provisions encourages settlements, thereby preventing many cases from reaching the courts. ${ }^{286}$ Because few cases in this arena are fully litigated, judges and courts cannot render opinions and perform their important norm-creating function. ${ }^{287}$ The trend away from legal liability undermines the ability of courts to provide signals regarding the kind of conduct that should receive condemnation, highlighting the need for legal sanctions to support reputational ones.

Another flaw in the argument against legal sanctions is that it fails to appreciate the important role legal penalties play in establishing norms. ${ }^{288}$ Just as legal opinions play a crucial role in generating norms, legal sanctions serve as an important barometer for measuring whether directors' conduct merits reputational sanctions. ${ }^{289}$ If directors receive no legal sanctions for their conduct, the extent to which that conduct appears objectionable is minimized. Thus, because the legal system rarely if ever holds directors personally liable for engaging in lax conduct, directors and the communities to which they belong may view such conduct as acceptable. ${ }^{290}$ As a consequence, the system

sanctions, these norms "stabilize only if they are internalized by a significant portion of the relevant social group." Id. at 1260.

285. See, e.g., Kuykendall, supra note 109, at 477-79 (discussing Gagliardi v. Trifoods International, Inc., 683 A.2d. 1049 (Del. Ch. 1996), which applied the business judgment rule to the conduct of directors but could not have been litigated had an exculpatory statute been in effect).

286. A.C. Pritchard, Who Cares?, 80 WASH. U. L.Q. 883, 886 (2002) ("As a result of the universal practice of settlement, officers and directors are usually able to walk away without paying anything. Directors' and officers' insurance pays a portion of settlements, with the corporation paying the remainder." (footnotes omitted)).

287. See supra note 285 and accompanying text (discussing the inability of courts to examine corporate conduct covered by exculpatory statutes).

288. See, e.g., Sunstein, supra note 283, at 958 (recognizing the importance of government regulation in enforcing and shaping norms).

289. David A. Westbrook, Corporation Law After Enron: The Possibility of a Capitalist Reimagination, 92 GEO. L.J. 61, 92 (2003) ("One way to inform a culture is through legal sanctions that punish those individuals who violate cultural norms."). Professors Blair and Stout recognize that lawsuits serve an important signaling function, but they caution that lawsuits may "suggest... that breach of duty is common, even normal, in business relationships[,]" which might encourage others to engage in similar conduct. Blair \& Stout, supra note 99, at 1798.

290. See John R. Kroger, Enron, Fraud, and Securities Reform: An Enron Prosecutor's Perspective, 76 U. CoLO. L. REV. 57, 111 (2005) (commenting that the failure 
supports the notion that engaging in lax conduct does not pose a risk to their reputation. ${ }^{291}$ From this perspective, because the corporate regime shields directors from being held liable, it undermines the effectiveness of reputational sanctions. In fact, it was not until our legal and political system openly condemned Enron officials that their reputations began to suffer. ${ }^{292}$ Prior to this condemnation, some of their peers appeared willing to defend the actions of Enron officials. ${ }^{293}$ This reinforces the notion that legal sanctions represent an important aspect of reputational sanctions. Because the legal regime is one of the lenses through which we judge the quality of an individual's reputation, that system must hold people liable for inappropriate behavior in order to signal that such behavior should be condemned by the community.

In this regard, an effective legal regime represents a necessary precondition to effective reputational sanctions. This interdependence also reveals the defects of relying solely on reputational sanctions to regulate director behavior.

2. Deterrence and the Laws of the Market. Like reputational sanctions, the market needs the support of the legal regime in order to perform its deterrent function properly. Professor John Coffee has emphasized the need to supplement a market-based system with federal regulation. ${ }^{294}$ Professor Coffee points out that a purely market-based system is incomplete in part because market professionals must rely on data provided to them by the issuer, and the market does not properly incentivize the issuer to provide full and honest disclosure voluntarily. ${ }^{295}$

to impose harsh legal penalties against corporate criminals in the late 1980s sent "the message that white collar crime [was] not serious").

291. See Michael B. Dorff, Softening Pharaoh's Heart: Harnessing Altruistic Theory and Behavioral Law and Economics to Rein in Executive Salaries, 51 BuFf. L. REv. 811, 847-48 (2003) (discussing that while reputational pressures provide some incentive for board members to independently audit the actions of the corporation's officers, maintaining one's board position provides far greater incentives).

292. See Ronald Brownstein et. al, The Nation: Washington Friends Desert Enron Chief; Energy: White House and Lawmakers Keep a Distance Amid Probe, L.A. Times, Dec. 15, 2001, at A1 (detailing the retreat of Enron's political allies after the company's highly-publicized demise).

293. See Sheila McNulty, Profile Kenneth Lay: Patriarch's Departure Leaves Mix of Feelings, Fin. TIMES (London), Jan. 25, 2002, at 24 (profiling Lay as having a "largerthan-life persona in Houston" prior to Enron's collapse and having been abandoned by "political beneficiaries" like George W. Bush after the company's demise).

294. See generally John C. Coffee, Jr., Market Failure and the Economic Case for a Mandatory Disclosure System, 70 VA. L. REV. 717 (1984).

295. See id. at 722-23. 
Others appear to agree that the market cannot perform its regulatory function without the support of the law. ${ }^{296}$

This support has two components. First, legal sanctions are necessary to counteract the market's tendency to encourage directors to be overly optimistic. Because positive financial results translate into higher stock prices, the market places considerable pressure on corporate managers and directors to take actions that ensure those results. ${ }^{297}$ In a climate in which the market reacts quickly to negative news, no one wants to be responsible for its publication. Consequently, the market may provide a strong incentive to corporate directors to publish overly optimistic news while ignoring red flags and failing to scrutinize officer conduct. $^{298}$ Because of this incentive, our corporate governance system needs legal sanctions to serve as a countervailing force, pressuring directors to pay heed to their fiduciary responsibility of ensuring the disclosure of corporate news, whether positive or negative.

Second, legal incentives are necessary to support market professionals' efforts to assess a corporation properly. The market depends on market professionals to evaluate available information about a given corporation. Market professionals, in turn, depend on corporations to provide them with relevant and accurate information. Enron revealed that if corporate officers manipulate or distort corporate information, then the role of market professionals-and thus the market-is undermined. Although market professionals bear some responsibility for

296. See Paredes, supra note 19, at 526.

297. See, e.g., Lawrence E. Mitchell, A Critical Look at Corporate Governance, 45 VAND. L. REV. 1263, 1287-92 (1992) (describing how stock prices can become a "surrogate for directorial performance"); Robert G. Vanecko, Regulations $14 \mathrm{~A}$ and $13 \mathrm{D}$ and the Role of Institutional Investors in Corporate Governance, 87 Nw. U. L. REV. 376, 410-14 (1992) (discussing market pressures to demonstrate strong financial results and analyzing whether institutional investors reduce such pressure); see also U.S. Senate Committee on Banking, Housing and Urban Affairs, Oversight Hearing on "Accounting and Investor Protection Issues Raised by Enron and Other Public Companies", 1318 PRACTISING L. INST. 535, 538 (2002) (prepared statement of Mr. Ira M. Millstein, co-chair of Blue Ribbon Committee on Improving the Effectiveness of Corporate Audit Committees, created by the NYSE and NASD at the request of the SEC) (noting the increased pressure to ensure short-term stock performance and satisfy financial expectations, which may encourage corporate actors to ignore shareholder value and engage in high risk actions).

298. See Mitchell, supra note 297, at 1287-92. It has been noted that regulation may be needed to curb the overly optimistic tendencies of directors and officers. See In re Caere Corp. Sec. Litig., 837 F. Supp. 1054, 1057-58 (N.D. Cal. 1993) (noting the optimism of corporate executives who have personal stakes in the company); Donald C. Langevoort, Disclosures That "Bespeak Caution," 49 Bus. LAW. 481 (1994) (discussing growth of the "bespeaks caution" doctrine to counteract optimism of corporate managers); Ribstein, supra note 34, at 2-3 (noting some tendency of "efficient securities markets" to be "overly optimistic"). 
failing to detect inaccurate corporate information, ${ }^{299}$ directors share the blame because they have a fiduciary responsibility to monitor the corporation's business affairs and the officers who report those affairs. ${ }^{300}$ Thus, directors must serve as a final check on the information officers provide to market professionals and the public. If directors believe they can ignore their responsibility without fear of significant legal reprisals, then they will fail to provide the necessary check on corporate misinformation. Without that check, the market cannot properly carry out its role. From this perspective, the market depends on legal sanctions because such sanctions ensure that directors carry out their corporate responsibilities, which in turn increases the potential that corporate information will be accurate.

This discussion indicates the need to ensure that legal liability represents a component of the framework for regulating corporate conduct. This Article does not advocate reliance solely on legal sanctions, any more than it advocates reliance solely on the market or reputational sanctions. Instead, legal liability should be used in combination with other measures for regulating director conduct. Such legal liability not only provides a powerful source of deterrence, but also buttresses extra-legal measures. ${ }^{301}$ Ultimately, legal liability is necessary both when these measures fail and in order for these measures to succeed.

\section{The Corporate Catch-22 and the Costs of Director Liability}

The conclusion that legal sanctions may be necessary to regulate director conduct appears to raise a dilemma for the existing corporate governance structure. First, scholars claim that too much personal liability is quite simply bad for business because it undermines the innovation necessary for businesses to thrive. $^{302}$ Second, scholars insist that too much exposure to personal liability will ultimately ensure that corporations cannot fill director positions by making such positions undesirable for most people. ${ }^{303}$ In this sense, legitimate risk of legal liability

299. See Millon, supra note 217, at 321 (noting that market analysts had "blind faith in Enron").

300. See supra notes 14-19 and accompanying text (explaining corporate directors' fiduciary duty of care to monitor corporate actors).

301. See supra notes 193-208 and accompanying text (discussing the interrelationship between legal liability and extra-legal measures-in particular, deterrence as affected by reputational concerns and market laws).

302. Cf. Balotti \& Gentile, supra note 183, at 8-9 (noting that the threat of personal liability "could force directors to act defensively out of concern over costly personal litigation").

303. See id. at 9 ("The general result has been that many qualified individuals have 
seems at odds with a corporate governance structure that relies on outside board members.

Many scholars maintain that if there is significant risk that directors can be held personally liable for their conduct on corporate boards, that risk will chill innovation and risk-taking to the detriment of shareholders. ${ }^{304}$ Under this rationale, because directors fear being punished for their innovation through hindsight assessments of their activities, directors always will choose the most conservative course of action, tending to reject transactions that involve any risk, even when some risk may be acceptable and necessary for the corporation to thrive. ${ }^{305}$ It certainly makes sense that directors who fear personal liability will be unwilling to make or approve decisions that appear even remotely risky. In fact, drafters of the Model Business Corporation Act's exculpatory provision recognized this potentially negative impact of legal liability when writing that Act. ${ }^{306}$ The drafters argued that directors needed protection from exposure to personal liability so that "directors would not be discouraged from fully and freely carrying out their duties, including responsible entrepreneurial risk-taking." ${ }^{307}$

However, this argument seems more applicable as a justification for a lower standard of review for directors' conduct than for eradicating liability altogether. Indeed, we employ the business judgment rule with a focus on corporate procedures to ensure that directors who use their business judgment are not subject to Monday-morning quarterbacking. ${ }^{308}$ If directors fail to comply with even that lax standard of judgment, there needs to be some risk that they will be held personally accountable.

Another argument against imposing legal sanctions on directors is that such an imposition would make people unwilling to serve as directors. ${ }^{309}$ This argument insists that the threat of

refused to serve as directors.").

304. See, e.g., id. at 10 (citing the synopsis to DEL. CODE ANN. tit. 8, $\S 102(2001)$ as noting that liability may deter directors from making entrepreneurial decisions); Frank H. Easterbrook \& Gregg A. Jarrell, Do Targets Gain from Defeating Tender Offers?, 59 N.Y.U. L. Rev. 277, 277 ("The business judgment rule gives managers the freedom to err, and thus it facilitates risk-taking.").

305. Cf. Phillips, supra note 193, at 683 (noting that the fear of litigation may cause corporate managers to choose the less risky or safe option even if it does not benefit the corporation).

306. See MOdEL Bus. CORP. ACT ANN. § 2.02(b)(4) cmt.i (2002).

307. Id.

308. See supra notes 89-93 and accompanying text (explaining the purpose of the business judgment rule).

309. See, e.g., Balotti \& Gentile, supra note 183, at 10 (quoting R. FrankLIN BALOTTI \& Jesse A. Finkelstein, The Delaware LaW of Corporations and Business 
millions of dollars in personal liability will be enough to dissuade people from serving as directors, especially given the relatively small amount of money outside directors receive for their service. $^{310}$ Certainly, after Enron and Sarbanes-Oxley, newspapers reported instances of corporations having difficulties with filling director vacancies as well as instances of people unwilling to serve as directors because of concerns regarding increased legal liability and decreased availability of D\&O insurance. ${ }^{311}$ Similarly, after Van Gorkom, newspapers reported instances of director resignations. ${ }^{312}$ The possibility that people may shy away from serving as directors may be even more salient because we now rely more heavily on outside directors. Indeed, outside directors have other means of employment and thus have less financial or occupational incentive to serve as directors, particularly when that service entails significant risk of legal liability. ${ }^{313}$ If imposing liability on directors discourages them from service, then our corporate governance system will be rendered inoperative.

However, because alternative measures have proved insufficient to deter director laxity, the corporate governance system must rely on legal sanctions and therefore must bear the cost associated with those sanctions. Even proponents of alternatives to legal sanctions concede that we must look towards legal sanctions when the alternatives prove ineffective. ${ }^{314}$ Enron suggests that the costs of eliminating liability completely and thereby allowing corporate malfeasance to go unchecked are simply unacceptable. For this reason, we must accept legal

ORganizations $\S 102 \mathrm{cmt}$. (3d ed. 2005)); Robert W. Hamilton, Reliance and Liability Standards for Outside Directors, 24 WAKE FOREST L. REV. 5, 28-30 (1989).

310. See Paredes, supra note 19, at 520-21 (noting that reform efforts may narrow the pool of potential candidates for directors).

311. See, e.g., Kemba J. Dunham, Reforms Turn Search for Directors into a Long, Tedious Task, WALL ST. J., Aug. 29, 2002, at B1 (reporting that "the once-routine task of finding a new director has suddenly become a time-consuming and often frustrating process for companies"); see also BLACK ET AL., supra note 101, at 1 n.4 (citing studies indicating that a significant percentage of people have declined board positions because of fear of increased liability).

312. See Laurie Baum \& John A. Byrne, The Job Nobody Wants, Bus. WK., Sept. 8, 1986 , at 56 (reporting resignations of outside directors due to the increased risk of liability and higher liability insurance); see also Taylor, supra note 126, at 1053 (noting that in the wake of Van Gorkom "many outside directors of public companies resigned, declined to stand for re-election or refused nomination").

313. See Hamilton, supra note 309 , at 28 (noting that, when faced with a serious risk of personal liability, outside directors often decide that the risks outweigh the benefits).

314. See Phillips, supra note 193, at 673 n.88 (remarking that it is appropriate to consider legal sanctions when extra-legal controls do not control undesirable conduct). 
sanctions and their attendant costs as a part of the corporate governance system.

It should be pointed out that the actual extent of these costs remains uncertain. Indeed, while there are reports of isolated director resignations, no real study of the impact that enhanced liability has on directors' willingness to serve exists, so there is no proof that such an enhancement will result in wholesale desertion of corporate directorships. In fact, there are some reasons to believe that directors may be willing to serve even in the face of potential increased liability. Certainly, the notion that directors will not serve if confronted with significant risk of legal liability appears particularly compelling considering that outside directors have other sources of income and that the salary they receive appears to be nominal. ${ }^{315}$ For example, Enron reported that its nonemployee directors receive an annual service fee of $\$ 50,000$ and $\$ 1250$ per board meeting and committee meeting. ${ }^{316}$ Given the number of meetings directors typically attend, Enron compensation for outside directors is inferably between $\$ 66,250$ and $\$ 82,500$ per year. ${ }^{317}$ When viewed against the costs of potentially millions of dollars in liability, this relatively modest amount does not necessarily seem a sufficient benefit. However, such an assessment fails to appreciate the nonmonetary benefits associated with serving as a director. Serving as a director represents membership in an elite club, conferring upon its members reputational and other benefits. Although increased liability may undermine the advantages of that club membership, it nonetheless represents an important aspect of a person's willingness to serve. Then too, directors' salaries may not be as nominal as they appear at first glance. Indeed, including cash and stock, the total remuneration fees for each Enron director in 2001 were roughly $\$ 380,000{ }^{318}$ Moreover, a study of the top 200 U.S. public companies revealed that the average total board compensation for such companies was nearly $\$ 140,000 .^{319}$ While the generous salary of Enron directors raises

315. See Baum \& Byrne, supra note 312 , at 54-58.

316. Enron Proxy Statement, supra note 196 at 12.

317. In 2000, all Enron directors attended at least $75 \%$ of the total number of meetings, which included nine board meetings and an additional eight to seventeen other meetings depending on the individual subcommittee. See id. at 9-10.

318. See Reed Abelson, Enron Board Comes Under a Storm of Criticism, N.Y. TIMES, Dec. $16,2001, \S 3$, at 4 .

319. See Subcommittee on Investigations Report, supra note 22, at $11 \mathrm{n} .9$ (citing NATIONAL Association of CORPORATE DiRECTORS, REPORT OF THE NACD BluE RibBON Commission on Director Compensation: Purpose, Principles, and Best Practices V (2001)). 
questions about their ability to monitor officers responsible for conferring upon them such a salary, it also suggests that some directors may be more willing to serve than the nominal characterizations of their salaries would suggest.

Nevertheless, given the fact that many directors do in fact receive a relatively small salary, the potential for at least some form of director desertion appears undeniable. Therefore, we must investigate ways to prevent this from occurring. Although a full assessment of measures for reducing this cost is beyond the scope of this Article, it is possible to make some suggestions about measures for consideration.

First, the need for legal sanctions may cause us to reconsider the utility of relying primarily, if not completely, on outside directors. Although enhancing directors' exposure to legal liability may have an impact on all directors, it may be particularly problematic for outside directors. Unlike inside directors, who rely on the corporation for their livelihood and may find it more difficult to refuse service as a director, outside directors have other employment and can more readily reject participation on boards. In this respect, even if corporations can find directors, augmenting legal sanctions may have the unintended consequence of making it more difficult to find directors outside the corporate enterprise. In the current climate, this difficulty has serious corporate governance implications. Indeed, reform efforts have emphasized the importance of ensuring that boards contain a majority of outside directors. ${ }^{320}$ Some reforms not only make this a requirement, ${ }^{321}$ but also require that certain committees, such as the audit and nominating committees, be comprised completely of outside directors. ${ }^{322}$ This Article suggests that these reforms cannot have it both ways-that is, they cannot require that boards include outside members and expose those members to real liability. Which of these goals should give way? The preference for outside directors reflects a belief that such directors will be less conflicted and thus better able to perform their monitoring

320. See Ribstein, supra note 34 , at 11-12 (describing various reform measures focusing on outside directors and director independence).

321. See NYSE Listing Standards § 303A.01(1), http://www.nyse.com/lcm (last visited Jan. 29, 2005) (requiring companies listed on the stock exchange to have a majority of independent directors).

322. See Sarbanes-Oxley Act $\S 301,15$ U.S.C. $§ 78 j-1(m)(3)$ (Supp. II 2002) (requiring audit committee to be comprised solely of independent directors); NYSE Listed Company Manual § 303A.04(8) (requiring members of the nominating or corporate governance committee to be independent, defined as not having any material relationship with the corporation). 
duties. Enron appears to support this belief. However, empirical evidence on the impact of outside directors is equivocal. ${ }^{323}$ Given this evidence, and the fact that enhancing directors' exposure to legal liability may make it more difficult to attract outside directors, perhaps we should reconsider the appropriateness of requiring the presence of outside directors.

Second, we might consider ways of capping directors' liability to reach a more optimal level of deterrence that would prevent instances of overdeterrence and make the cost of serving as a director more acceptable. Such a cap seems appropriate if the goal of legal liability is to deter director conduct and not to compensate shareholders and other victims. Of course, it is difficult without further research to determine what an optimal level of liability would be. Indeed, Professors Black, Cheffins, and Klausner have pinpointed some of the difficulties with determining an optimal cap for director liability, particularly when too low a cap may mean that plaintiffs have no incentive to bring suits against directors. ${ }^{324}$ However, Sarbanes-Oxley's provisions regarding officers may provide a useful blueprint. Indeed, directors could be subject to a maximum fine, a maximum prison term, or both when found to have violated their responsibilities under the Act. ${ }^{325}$ These ceilings could be similar to those imposed on officers. Moreover, directors could be required to disgorge any fees received if found to have breached their monitoring duty. ${ }^{326}$ Sarbanes-Oxley includes a disgorgement provision for CEOs and CFOs even if they are not found liable for

323. Indeed, several scholars have noted the equivocal evidence on board independence and firm performance. See, e.g., Bainbridge, supra note 34, at 375-76, 38690, 393-96 (criticizing the NYSE's listing standard that requires independent board members and presenting evidence that the committee's assertions for the requirement were misplaced); Lynne L. Dallas, Proposals for Reform of Corporate Boards of Directors: The Dual Board and Board Ombudsperson, 54 WASH. \& LEE L. REV. 91, 111-14 (1997) (discussing the mixed results of independent director studies); Jill E. Fisch, Taking Boards Seriously, 19 CARDOZO L. REV. 265, 276-80 (1997) (declaring "evidence demonstrating a relationship between independence and profitability" to be "in short supply"); Donald C. Langevoort, The Human Nature of Corporate Boards: Law, Norms, and the Unintended Consequences of Independence and Accountability, 89 GEO. L.J. 797, 797-99 (2001) (reporting that the "trend toward independence ... has encountered an empirical sticking-point"); Ribstein, supra note 34, at 26-27 (discussing some "inherent limitations on independent directors' effectiveness"). See generally Sanjai Bhagat \& Bernard Black, The Non-Correlation Between Board Independence and Long-Term Firm Performance, 27 J. CORP. L. 231 (2002) (reporting empirical evidence challenging the idea that independent directors are essential to good corporate governance).

324. See BLACK ET AL., supra note 101, at 54-58.

325. See supra Part III.A (outlining the liability of officers who have violated their duties).

326. Disgorgement of fees is not included in current director liability laws. See supra Part III.C.2 (examining director liability). 
corporate wrongdoing. ${ }^{327}$ A similar provision for directors who are found to have breached their responsibilities seems appropriate. Including such liability provisions for directors may present a more optimal level of risk for directors and may be an important first step towards ensuring that we create some mechanism for holding directors accountable for failing to perform their responsibilities.

This subpart reveals that while imposing legal liability on directors may entail some costs, those costs not only may be exaggerated, but also may be minimized. More importantly, given the importance of legal liability to the regulation of director conduct, such costs must be absorbed into any corporate governance system.

\section{CONCLUSION}

Corporate statutes confer upon directors an awesome power to oversee corporations and the officers within those corporations. With that power comes an obligation to ensure its proper execution. Moreover, it seems inappropriate to allow directors to delegate their power and then wash their hands of any responsibility when the officers to whom they delegate the power fail to exercise it appropriately. Indeed, the monitoring functions inherent in directors' fiduciary obligations recognize the vital role directors must play in ensuring that officers do not misuse their corporate authority.

Despite the significant impact that can stem from directors' failure to curb abuses of that power, most scholars appear to believe that legal penalties are not necessary to ensure that directors comply with their obligations. These scholars insist that extra-legal sanctions make legal penalties unnecessary, although the cost of those penalties, particularly the possibility that directors will refuse to serve or that they will serve in an overly cautious manner, makes them undesirable. Thus, these scholars support the current legal regime that ensures that directors face little, if any, legal liability for failing to meet their fiduciary duties.

327. Section 304 of Sarbanes-Oxley provides that if an issuer must prepare an accounting restatement due to noncompliance with financial reporting requirements under the federal securities laws and such restatement results from misconduct, the CEO and CFO of the issuer must reimburse the issuer for any bonus, or other incentive-based or equity-based compensation received and any profits realized from the sale of securities during the twelve-month period following the public issuance or filing of such financial reporting requirement. See Sarbanes-Oxley Act § 304, 15 U.S.C. § 7243 (Supp. II 2002). 
This Article argues that the regime's refusal to impose legal liability on directors makes it defective, particularly given the tremendous responsibility the regime gives to directors. In shying away from direct legal sanctions and relying on extralegal forces to regulate director conduct, Sarbanes-Oxley appears to repeat the mistakes of the current regime. Based on the lessons learned from recent corporate governance debacles, it is clear that extra-legal sanctions are not enough to ensure that directors devote enough attention to their responsibilities. Instead, this Article demonstrates that extra-legal sanctions cannot be effective without the support of legal penalties. This Article also demonstrates that legal sanctions have tremendous power to shape director behavior and that it is both necessary and appropriate to make use of that power in an effort to prevent director misbehavior. Indeed, this Article concludes that although legal liability has some costs, and hence its rod should not be used without an appreciation of those costs and an attempt to minimize them, sparing directors that rod altogether may encourage them to engage in lax behavior to the detriment of shareholders and the public alike. 